\title{
Rock Slope Stability Analysis by Using Integrated Approach
}

\author{
Dyson Moses*, Hideki Shimada, Takashi Sasaoka, Akihiro Hamanaka, Tumelo K. Dintwe, \\ Sugeng Wahyudi
}

Department of Earth Resources Engineering, Faculty of Engineering, Kyushu University, Fukuoka, Japan

Email: *moses18r@mine.kyushu-u.ac.jp

How to cite this paper: Moses, D., Shimada, H., Sasaoka, T., Hamanaka, A., Dintwe, T.K. and Wahyudi, S. (2020) Rock Slope Stability Analysis by Using Integrated Approach. World Journal of Engineering and Technology, 8, 405-428.

https://doi.org/10.4236/wjet.2020.83031

Received: May 18, 2020

Accepted: August 1, 2020

Published: August 4, 2020

Copyright (c) 2020 by author(s) and Scientific Research Publishing Inc. This work is licensed under the Creative Commons Attribution International License (CC BY 4.0).

http://creativecommons.org/licenses/by/4.0/

\begin{abstract}
Slope stability assessment is an essential aspect of mining and civil engineering. In this study, Songwe open-pit mine in Malawi was investigated to establish possible pit slope instability. In performing the analysis, an integrated approach entailing rock mass characterisation, kinematic and numerical methods were applied. Based on rock mass classification system, Songwe Hill carbonatite rock mass is characterised as a good rock but still it possesses numerous random discontinuities that present a complex challenge in geotechnical engineering. Dip 6.0 software was used in carrying out kinematic analysis based on the attributes of discontinuities. The results show that there is a $16 \%$ likelihood of planar failure in the divided slope sections of the planned pit. Thus, slope angle optimisation to $41^{\circ}$ has been proposed as a counter-measure to minimise the potential risk of planar failure. At the optimised angle, the risk of planar failure could be reduced by $44 \%$. On the other hand, wedge failure was found to be improbable since no joint intersections were found in the critical zone of potential failure. For numerical analysis, finite element code was applied using FLAC $^{3 \mathrm{D}} 5.0$ application. The results demonstrate that overall slope angle of $41^{\circ}$ would offer a favourable balance between safety and mining economics as mining operations progress to deeper horizons thereby avoiding a costly push back solution due to instability.
\end{abstract}

\section{Keywords}

Songwe Hill, Carbonatite, Kinematic Analysis, Numerical Analysis, Slope Stability

\section{Introduction}

Slope stability assessment is an essential aspect of mining and civil engineering. 
Depending on the analysis technique, the assessment can be aimed at: identifying endangered slope sections, investigating potential failure mechanisms, determining the slope sensitivity to different triggering mechanisms, designing of optimal slopes with regard to safety, reliability and economics and testing the efficacy of different support and stabilisation options [1]. Despite advancements in the computer-based slope stability analysis, slope instability still poses a major challenge in large mining operations. Llano-Serna et al. [2] quantify that roughly, two open pit failures occur worldwide annually. It is articulated that large and deep instability typically involves rock and is strongly influenced by the orientation and spacing of discontinuities existent in the rock mass as compared to near surface slope instability which is particularly influenced by soil properties and soil-water interaction [3] [4] [5] [6] [7]. Read \& Stacey [8] also highlight that as surface mining operations are expanding and getting deeper, the influence of in situ stresses could be of reckon to slope instability. This compounding effect in slope stability has to be accorded attention as the demand for mineral resources increase to cater for the world booming population.

In order to make accurate mine design, a thorough site investigation that includes geological and discontinuity mapping should precede stability studies to supply necessary and accurate input data for the stability analysis. This is because occurrence of slope failures in unstable mine slopes may affect the mining operations due to fatality, machinery damage and render the recovery of ore uneconomical if the mine was being actively mined [7] [8]. For instance, in 2012 a fatal slope failure left casualties at Jwaneng large diamond mine in Botswana. The incident lead the company to resort to a push back and dip slope mining solution after recognising the structural complexity of the country rock [9] [10]. The failure at the mine was apparently triggered by a planar release along a structural bedding that dips $20^{\circ}-30^{\circ}$ northwest which is the only section of the mine with a layered (anisotropic) rock mass [11] [12]. Thus, from the initiation of the mining projects, it is crucial to undertake a robust stability evaluation and design to better understand the rock mass, and methods of analysis that can model the rock mass and take into account variability in all of the geotechnical parameters [13].

In the case of the study area, the discovered rare earth elements (REE) deposit has a surface disseminated mineralisation style that will inevitably require surface mining method, specifically open-pit mining. The geological and structural mapping of the carbonatite complex at the Hill has shown that the rock mass possesses numerous random discontinuities which present a complex challenge in geotechnical engineering. These discontinuities may adversely affect the rock slope stability, potentially culminating in failures. In addressing such a geotechnical engineering problem, the study employs a combination of methods to evaluate stability conditions of the mine. Kinematic analysis, as a conventional method, graphically examine modes of slope failures that can possibly occur in a rock mass with respect to an existing or proposed rock slope [5] [14] [15] [16] [17]. 
The method analyses the displacement of geological materials along structural planes with no reference to the forces that induce the movement. Thus, kinematic analysis, which is capable of handling large discontinuity data sets, is undertaken first to assess possible modes of failure. On the other hand, numerical modelling complements in understanding the stability conditions by simulating the effect of stress distribution on the slope.

A good number of cases have been investigated applying kinematic analysis [3] [17] [18] [19] [20]. For instance, in a study by [18] found planar sliding failures were predominant in some of benches with high dip angle $\left(45^{\circ} \leq \alpha \leq 55^{\circ}\right)$ which he described as not ideal for mine stability. Furthermore, the rock mass was prone to sliding along the foliations particularly at low angles $\left(31^{\circ}-33^{\circ}\right)$. The condition was argued to be due to greater size of the component force in the direction of sliding of the foliation planes with an angle of $31^{\circ}$ than the ones with higher dip angles as well as their surfaces with nearly planar-slightly rough surfaces and mica flakes positioned in such a manner that is parallel to the foliation surfaces. However, the common trend in studies that apply kinematic analysis, use the method independently without evaluating the stress conditions on the slopes. Therefore, this study takes an integrated approach in the assessment of pit slope instability on a planned Songwe open-pit mine for optimal design.

\section{Location and Geology of Study Area}

Songwe hill is situated in Phalombe district southern Malawi (Figure 1). The Hill has a North-South diameter of $800 \mathrm{~m}$ and measures $450 \mathrm{~m}$ East to West. The planned open-pit mine at the site is anticipated to cover almost the whole stretch of the hill. The overall dimensions of the pit will be approximately $650 \mathrm{~m}$ North to South and $400 \mathrm{~m}$ East to West. Regarding pit height, it is expected that the deepest level will be $300 \mathrm{~m}$ when measured from the highest reduced level $(\mathrm{RL})$ of the pit on the southern side of the pit (Figure $1(\mathrm{c})$ ). The current, prefeasibility studies show that the mine will produce 8.536 million tonnes of ore and 26.930 million tonnes of waste at a 3.15 strip ratio [21]. The mine life is projected to take 18 years of mining activity.

In terms of regional geology, the area lies within the Chilwa Alkaline Province (CAP) (Figure 1). The area is underlain by crystalline rocks of Precambrian to lower Palaeozoic age referred to as the Malawi Basement Complex which is intruded into by alkaline intrusive bodies [22] [23]. The emplacement of these alkaline intrusions occurred during the Late Jurassic-Early Cretaceous period which affected an area approximately $300-400 \mathrm{~km}$ in diameter in the south of Malawi and in Mozambique (Figure 1). At various localities, the basement complex is overlain by sequence of Permo-Carboniferous to lower Jurassic sedimentary rocks of the Karoo supergroop and superficial Tertiary to recent Karoo sediments.

The local geology of the study area is principally composed of; carbonatite and 
fenite surrounded by a massive intrusion of syenite (Figure 1(b)). Carbonatite, which is the ore hosting rock, is best exposed on the north and north-eastern slopes with relatively smaller extent on the northwestern slope. There are essentially three REE mineralised carbonatites namely: coarse grained calcite carbonatite (soviet); fine grained carbonatite (alvikite); and Fe-rich ferroan calcite carbonatite.

Fenites form an aureole around the carbonatite intrusion. Large blocks of fenite show evidence of being in situ. They are interpreted as fractured blocks from the margins, or the roof of the carbonatite. It is postulated that the carbonatite intrusion never reached the surface since the fenite is continuous with only rare carbonatite veinlets [24]. In terms of the texture, the fenites display a coarsegrained equigranular igneous texture, strongly suggesting an igneous protolith. The fenitisation at Songwe is predominantly potassic with a composition of orthoclase and minor aegirine.

Secondary geological units at the site consist of veins of manganese and iron (Mn-Fe) and phonolite dykes. Broom-Fendley, et al. [24] presented new petrographic and geochemical observations following thin sections where he uncovered veins of flourite, apatite, calcite/ferroan-calcite, quartz and barite with accessories that include xenotime, zircon, rutile, hematite, synchesite and parasite.
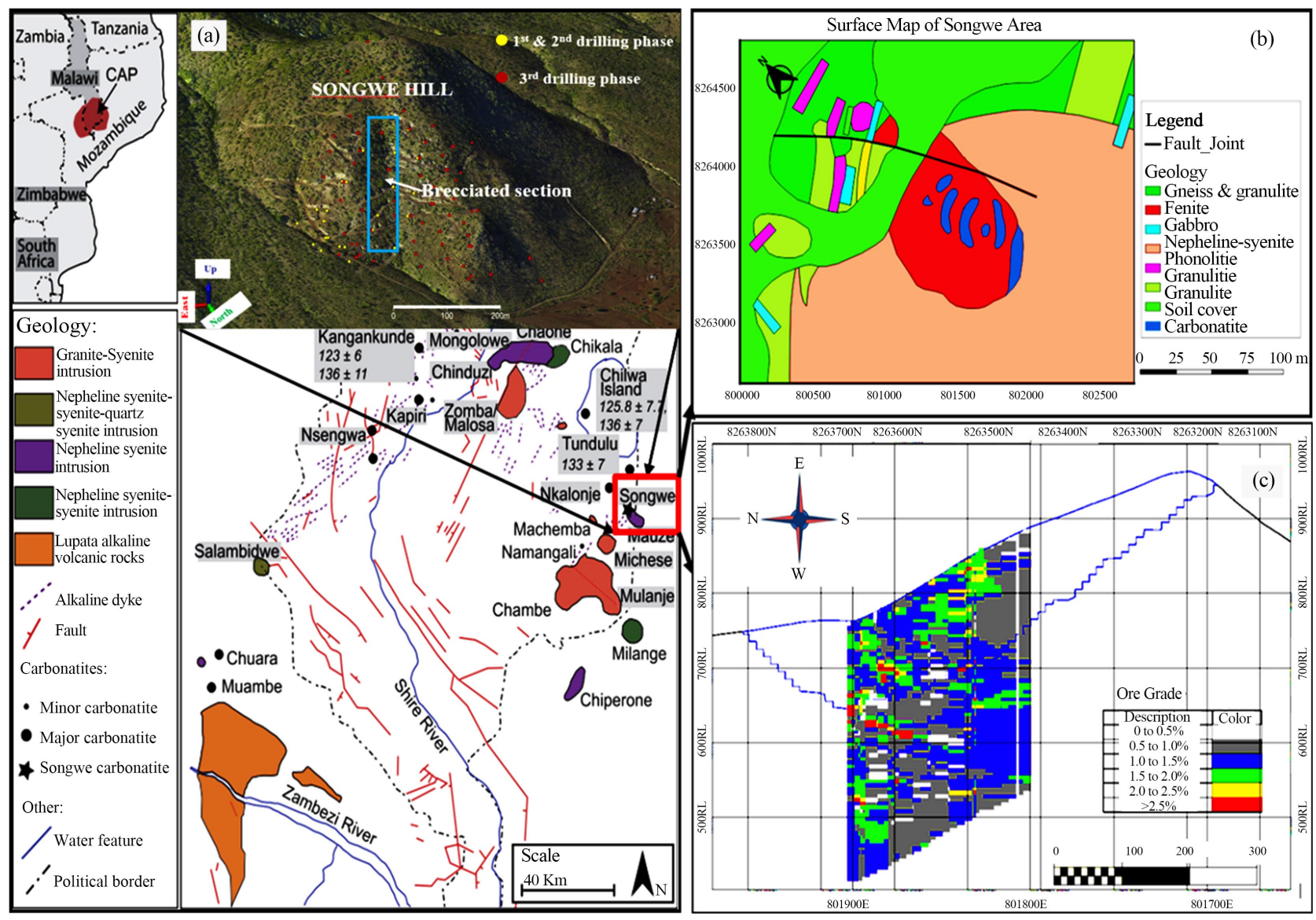

Figure 1. Location and geology of study area (Modified after [24]). 
Regarding structural geology, the site is within the active tectonic environment of the Malawi Rift system (MRS) which is part of the main East African Rift System (EARS). Thus, faulting and development of joints may not be an uncommon phenomenon. However, the structural disruption at the carbonatite complex is not vividly reflected on a large scale except for a major fault on the eastern side of the hill that runs NW to SE (Figure 1(b)). The subtle evidence of structural deformation is revealed in sharp lithological breaks across the hill. One of the structural patterns in the area is an apparent offset of fenite breccia body. The fenite-brecciated section is characterised by a depression between the apparent ridges on the north facing section of the hill as it can be observed in Figure 1(a).

Witley et al. [25] demonstrated that the lithological breaks correspond well with the faults interpreted from the ground magnetic survey although it is admitted that the fault traces were considered as an approximation (Figure 2). The low confidence in the magnetic data is premised on the fact that the resolution of the magnetic image was low at the scale of the geological map.

The surficial predominating structural features at the study site are joints. Surface geological mapping conducted revealed that the joints have different orientations. It was also discovered that most of the joints are healed by rough cementing calcite infill (Figure 3). This type of infill in the joints could generate enough impact to minimise chances of sliding compared to soft clay infill. This is because the binding effect of calcite could enhance cohesion between rock blocks.

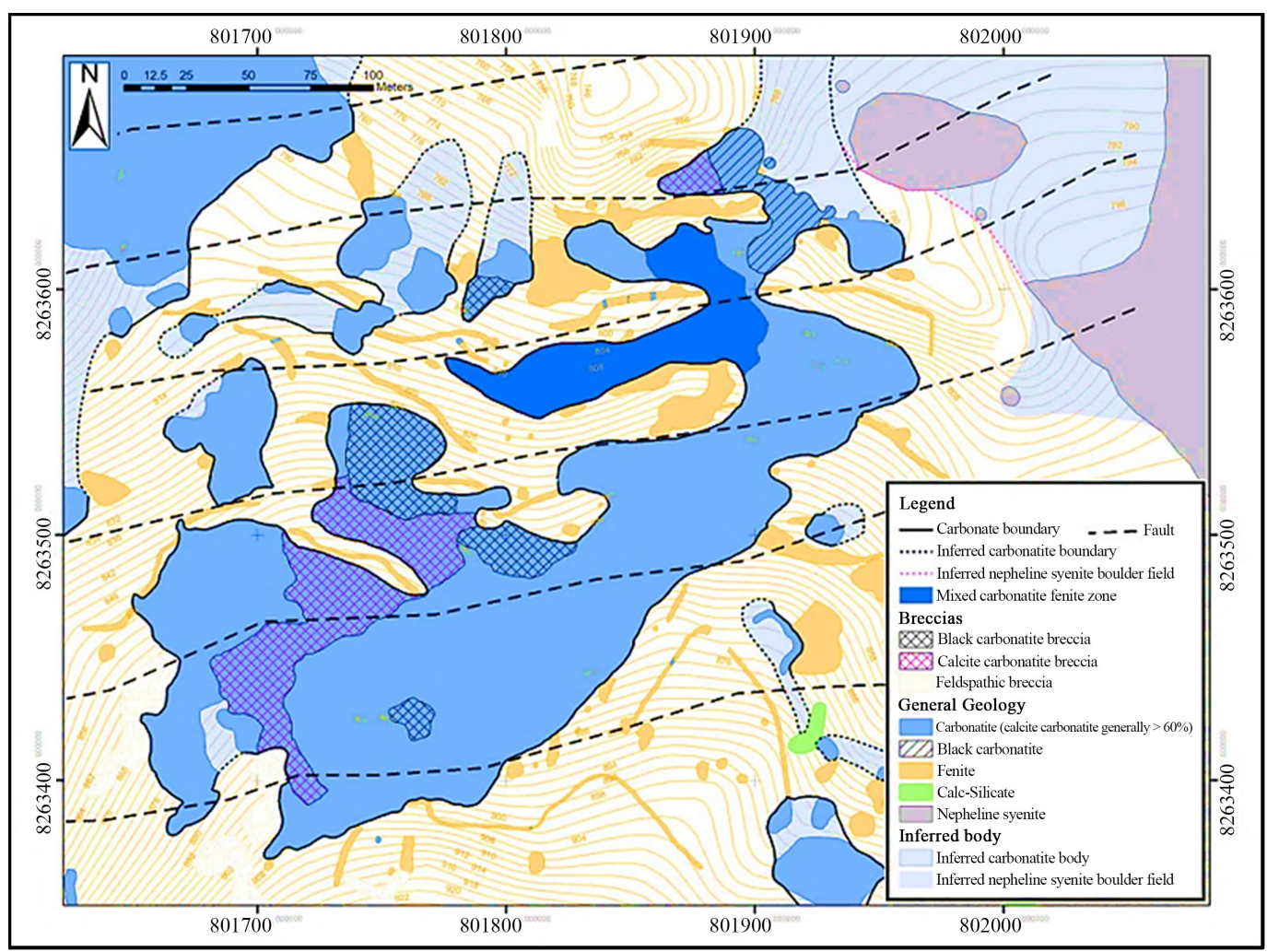

Figure 2. Geological map with faults (long dashed lines) interpreted from a ground magnetic survey [25]. 

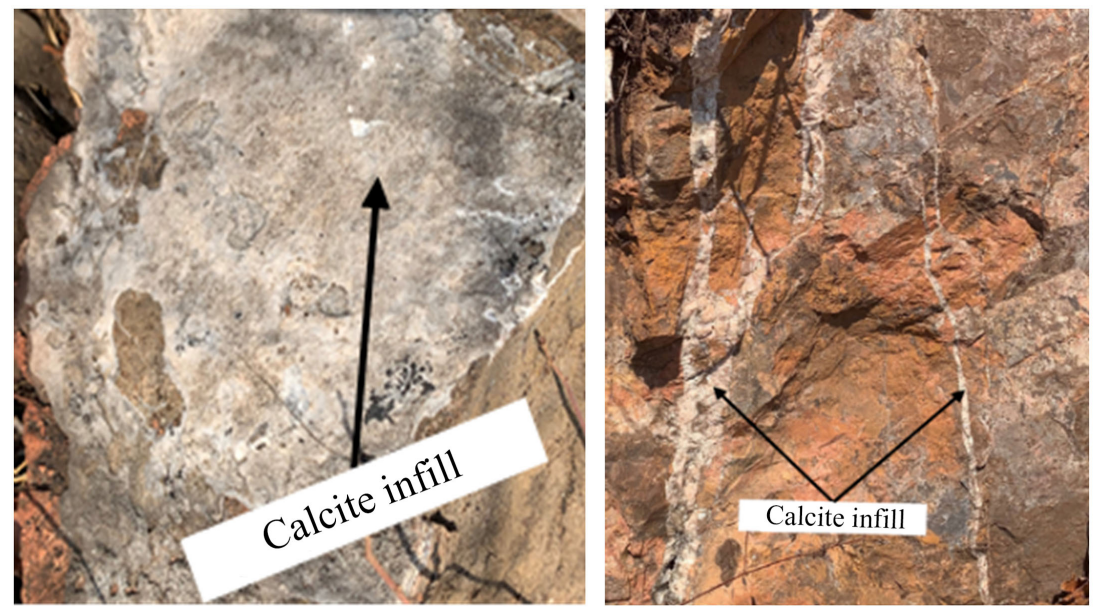

Figure 3. Predominating calcite infill in joints (Pictures taken by first author).

\section{Methods and Materials}

The approach to the study is summarised in Figure 4. The input data for the study was obtained from field investigation and laboratory experiments. Field investigations involved geological and structural mapping and geotechnical logging. Geotechnical log sheets provided discontinuity information; rock quality designation (RQD), joint spacing and joint conditions carefully recorded from diamond drill core. The data was logged at a regular interval of a 3 meter run, as such an average value was computed to characterise the rock on each drill hole. Persistence of joints was determined through scan line mapping of rock cuts created when making drill pads. The length of majority of the joints extended up to 3 meters.

To determine rock material properties, laboratory tests were conducted on representative samples collected from drill holes. The samples were prepared according to International Society of Rock Mechanics (ISRM) standards [26].

In order to comprehend the characteristic behaviour and rock conditions of the carbonatite complex, rock mass classification was performed based on a quantitative Rock Mass Rating (RMR) system and a correlation to qualitative system was done. Among the available classification systems, RMR system was selected based on its easiness and versatility in engineering practices, involving tunnels, mines, slopes, and foundations. In addition, the method has stood the test of time with a high global acceptance owing to its varied applications amounting to over 351 case histories [27]. As applied in slope analysis the method makes use of the five basic parameters to characterise a rock mass. The parameters include: UCS of rock material, RQD, discontinuity spacing $\left(J_{s}\right)$, condition of discontinuity surface (joint length $\left(J_{l}\right)$, joint aperture $\left(J_{a}\right)$, joint roughness $\left(J_{r}\right)$, joint infill $\left(J_{i}\right)$ and joint weathering $\left.\left(J_{w}\right)\right)$ and groundwater conditions (GW). RQD is derived as a percentage of the sum of intact core pieces longer than $10 \mathrm{~cm}$ divided by the total length of core run. The RMR method can be presented statistically as: 


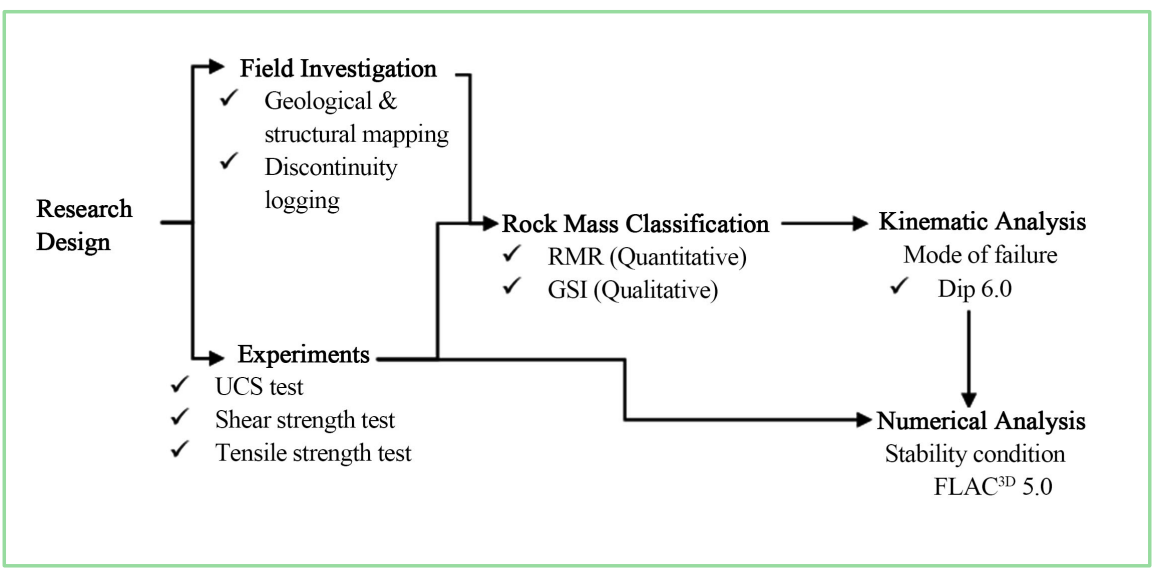

Figure 4. Study procedure.

$$
R M R=\sum_{i=1}^{5} R_{p} \quad \text { [27] }
$$

where $R_{p}$ is the rating of each of the five parameters.

To perform the kinematic analysis, Dip 6.0 software [14], was used in plotting the discontinuities based on the dip and dip direction of the joints. Dip 6.0 is an application designed to analyse features related to engineering analysis of rock structures. The program permits the analysis and visualisation of structural data employing similar techniques applied in manual stereographic projections. The parametric setting of the analysis entailed friction angle set at $35^{\circ}$ based on shear strength test results. This value is represented by a plane circle termed friction cone in the stereonet determined by counting the great circles of the stereonet from outside inwards. The dip of the overall pit slope was set at the maximum possible angle of $45^{\circ}$ and the direction was varied with respect to the slope face as $360^{\circ}$ or $0^{\circ}, 90^{\circ}, 180^{\circ}$, and $270^{\circ}$. The slope angle $(\alpha)$ of the slope face is represented by curved plane in the stereonet. Lastly, dip of the discontinuities $(\beta)$ and dip directions are represented by vector points since the number of joints is high. The analysis was carried out in a pole vector mode and discontinuities from drill hole logging were assumed continuous and through-going since there is no excavated surface to ascertain continuity.

For numerical analysis, finite difference method (FDM) using FLAC $^{3 \mathrm{D}} 5.0$ software was applied in simulating the potential slope instability of the pit slope. The FDM approach was preferred because the constitutive models are handled with no adjustment to the solution algorithm as such the modelling is justifiably more accurate for plastic collapse loads and plastic flow [28]. The analysis was performed in elasto-plastic state in finding the solution with Mohr-Coulomb constitutive model and failure criterion. To determine the safety factor of the stability, Shear Strength Reduction (SSR) technique is used in FDM code. The SSR involves a systematic iterative search of the factor of safety (FOS) value that stretches the slope to limits of failure. The Mohr-Coulomb materials were factored or reduced to determine the safety factor as presented in Equation (1): 


$$
\frac{\tau}{F}=\frac{c}{F}+\sigma \frac{\tan \varphi}{F} \quad[28]
$$

where: $\tau$ is shear stress, $c$ is cohesion, $\varphi$ is internal friction angle, $\sigma$ is normal stress, and $\mathrm{F}$ is slope safety factor.

The model was governed by the following boundary conditions; roller boundaries were assigned in the $x$ - and $y$-direction thereby fixing the boundary planes in the $x^{-}$and $y$-direction respectively, pinned boundary (i.e., constrained in the $x$-, $y$ - and $z$-directions) was applied at the bottom of the model and an unconstrained boundary at the top of the model. The material properties used in the study are presented in Table 1 . Rock density $(\gamma)$, UCS, Young's modulus $(E)$, tensile stress $\left(\sigma_{t}\right)$, friction angle $(\varphi)$, cohesion $(c)$ and Poisson ratio $(v)$ were obtained from rock strength tests conducted. Whereas bulk modulus $(K)$ and shear modulus $(G)$ were derived from Young's modulus values applying the formula below:

$$
\begin{aligned}
& \text { Shear Modulus }(G) \frac{E}{2(1+v)} \quad[28] \\
& \text { Bulk Modulus }(K) \frac{E}{3(1-2 v)} \quad[28]
\end{aligned}
$$

Two scenarios were considered in the modelling. In the first scenario, shear strain behaviour on the pit-slope was investigated at the current planned depth of $250 \mathrm{~m}$. The planned depth is within the bounds of proven ore reserve hence the geological confidence is high. The second scenario is for the ultimate depth of $300 \mathrm{~m}$. At this depth, the geological confidence is relatively low since less than $10 \%$ of the drilled holes reached $300 \mathrm{~m}$. In both cases, the analysis was conducted at different overall slope angle (OSA). The stability of the pit walls was also assessed by varying the rock mass parameters based on the GSI values that fall in the rock mass class. The adjusted parameters (UCS, cohesion, friction angle and tensile strength) were derived by using Rocklab 1.0 software [29]. The application converts the Hoek-Brown classifying parameters into a Mohr-Coulomb fit applicable to FLAC $^{3 \mathrm{D}}$.

\section{Results and Discussion}

\subsection{Rock Mass Classification}

The major aim of rock mass classification is to provide a common basis for effective communication concerning geomechanical problems that could be associated with the rock mass condition. As such, the representative RMR value established in the study and its interpretation adhere to a set of the system's guidelines. The summary of the results is presented in Table 2. From the results, the rock mass at the study site has an RMR value of 62 which can be described as a good rock with a rock class of "II" [30].

The evaluated quantitative RMR value was correlated to qualitative rock mass 
characterisation for validation. Geological Strength Index (GSI) system, introduced by Hoek in 1994, is a widely accepted qualitative scheme for describing the rock mass reliably fast and simple [31]. The method is a result of a combination of observations of the rock mass conditions (Terzaghi's descriptions) with the relationships developed from the extensive experience gained using the RMR-system. Thus, the relationship between rock mass structure and rock discontinuity conditions is used to estimate an average GSI value represented in the form of diagonal contours. The GSI value was empirically correlated to RMR based on the relationship formula by Singh \& Goel [30] as:

Table 1. Mechanical properties of the rock units.

\begin{tabular}{cccccccccc}
\hline Rock Type & $\begin{array}{c}\mathrm{UCS} \\
(\mathrm{MPa})\end{array}$ & $\gamma\left(\mathrm{g} / \mathrm{m}^{3}\right)$ & $E(\mathrm{GPa})$ & $G(\mathrm{GPa})$ & $K(\mathrm{GPa})$ & $\begin{array}{c}\sigma_{t} \\
(\mathrm{MPa})\end{array}$ & $\varphi(\mathrm{Deg})$ & $C(\mathrm{MPa})$ & $V$ \\
\hline Carbonatite & 83.20 & 2.78 & 45.30 & 17.7 & 34.30 & 8.6 & 35 & 0.32 & 0.28 \\
Fenite & 118.6 & 2.70 & 44.40 & 17.2 & 35.20 & 10.4 & 36 & 0.30 & 0.29 \\
Phonolite & 150.4 & 2.88 & 64.30 & 24.7 & 51.00 & 11.5 & 37 & 0.45 & 0.29 \\
Syenite & 70.00 & 2.55 & 70.00 & 7.21 & 10.42 & 3.37 & 30 & 0.28 & 0.25 \\
\hline
\end{tabular}

*Based on empirical values [21].

Table 2. Rock mass characterisation of Songwe carbonatite complex.

\begin{tabular}{|c|c|c|c|c|c|c|c|c|c|c|}
\hline \multirow{2}{*}{ Hole id } & \multirow{2}{*}{ UCS } & \multirow{2}{*}{ RQD } & \multirow{2}{*}{$J_{s}$} & \multicolumn{5}{|c|}{ Condition of Discontinuities $\left(J_{c}\right)$} & \multirow{2}{*}{ GW } & \multirow{2}{*}{$\mathrm{RMR}^{\star}$} \\
\hline & & & & $J_{l}$ & $J_{a}$ & $J_{r}$ & $J_{I}$ & $J_{W}$ & & \\
\hline PX038 & 7 & 13 & 10 & 4 & 1 & 3 & 2 & 3 & 15 & 58 \\
\hline PX045 & 4 & 13 & 10 & 4 & 4 & 5 & 4 & 3 & 15 & 62 \\
\hline PX051 & 4 & 8 & 8 & 4 & 1 & 3 & 0 & 1 & 15 & 44 \\
\hline PX055 & 12 & 13 & 10 & 4 & 1 & 3 & 2 & 5 & 15 & 65 \\
\hline PX057 & 7 & 17 & 15 & 4 & 4 & 5 & 4 & 3 & 15 & 74 \\
\hline PX058 & 7 & 17 & 15 & 4 & 4 & 5 & 4 & 3 & 15 & 74 \\
\hline PX059 & 7 & 17 & 10 & 4 & 1 & 5 & 2 & 3 & 15 & 64 \\
\hline PX063 & 7 & 17 & 10 & 4 & 1 & 5 & 2 & 3 & 15 & 64 \\
\hline PX070 & 4 & 13 & 10 & 4 & 1 & 5 & 2 & 3 & 15 & 57 \\
\hline PX077 & 7 & 17 & 10 & 4 & 4 & 5 & 2 & 3 & 15 & 67 \\
\hline PX087 & 7 & 13 & 10 & 4 & 1 & 3 & 2 & 5 & 15 & 60 \\
\hline PX089 & 7 & 13 & 10 & 4 & 1 & 3 & 2 & 5 & 15 & 60 \\
\hline PX093 & 7 & 13 & 10 & 4 & 1 & 5 & 2 & 3 & 15 & 60 \\
\hline \multicolumn{10}{|c|}{ Average } & 62 \\
\hline
\end{tabular}

${ }^{*}$ Computed as the sum of the rock mass characterisation parameters. 


$$
\mathrm{GSI}=\mathrm{RMR}-5
$$

The GSI value of the Songwe carbonatite is computed to be 57. Thus, the qualitative interpretation of the rock mass based on computed GSI value implies that the rock mass is a good rock with a structure of multi-faceted angular blocks generated by three or more joint sets with a surface quality of being rough, slightly weathered and iron stained surface. The description is quite in agreement with the quantitative RMR interpretation of the rock mass characterisation. The GSI value is significant in this study for assessing rock strength condition at the modelling stage.

\subsection{Kinematic Analysis}

\subsubsection{Planar Failure}

For planar failure to occur, the joint plane has to dip downward in almost the same direction as the slope face at a less steep angle. Where the joint plane is exposed in the slope face, the plane is regarded to "daylight", a condition conducive for rock mass sliding. Hoek E. \& Brady [5], Kliche [32] and Goodman, 1989 [4] proposed that the following conditions must be fulfilled for planar sliding to occur on a discrete plane.

1) The plane on which sliding occurs must strike parallel or nearly parallel (within approximately $+/-20$ degrees) to the slope face.

2) The failure plane must "daylight" in the slope face. This implies that the dip of the slope face must be steeper than the apparent dip of the failure plane.

3) The dip of the failure plane must be greater than the angle of friction of this plane.

The performed analysis shows that the risk of potential planar failure is relatively high on the north facing section of the Songwe mine. The kinematic analysis indicates that 83 joints in the north facing section would be critical in influencing planar slope failure of the planned pit (Figure 5). This represents a $17 \%$ probability of failure for a sectional north dipping joints and a crude $6 \%$ probability with respect to all the plotted joints. In the east and west facing section of the planned pit, the risk of failure is relatively low with 55 and 51 joint planes plotting in the critical zone of potential failure respectively (Figure 6 \& Figure 7). Statistically, the probability of failure for the slopes is at $17 \%$ in both cases when considering the discontinuities in the respective sections. However, the crude probability of failure is at $4 \%$ in the eastern section and $3.7 \%$ in the western section.

The section with the lowest risk of failure is the south facing section, which has 36 joint planes plotting in the critical zone of potential failure (Figure 8). This represents a $13 \%$ sectional probability of failure and a crude probability of $2.6 \%$. Thus, the sectional overall probability of planar failure of the entire mine is $16 \%$ which is high against the acceptable stability criteria empirically determined by [8] [17] [33].

To minimise the potential risk of planar failure identified in the analysis, 
slope angle optimisation would be crucial. In mining, exploitation of ore in open pit mine involves relating slope angle design to a pair of contradiction between resource recovery and safety. The heightening and steepening of excavation bench slopes may affect the security of the overall slope thereby inducing instability. Thus, Slope angle optimisation helps in striking a balance between safety and mining economic profits. Based on the current analysis, an optimised slope angle could be adopted within an acceptable angle between $40^{\circ}$ and $45^{\circ}$.

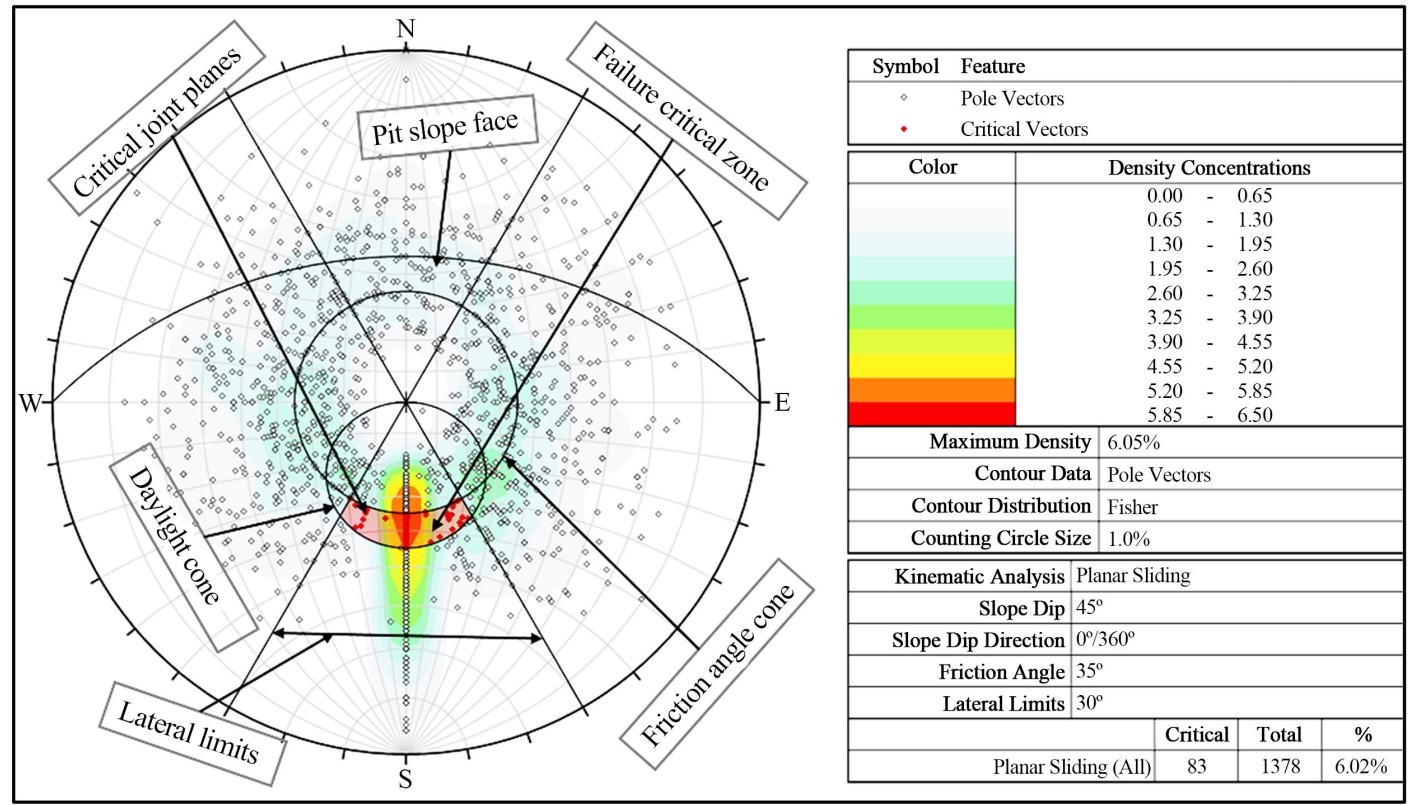

Figure 5. Planar slope stability condition in north facing pit slope at an angle of $45^{\circ}$.

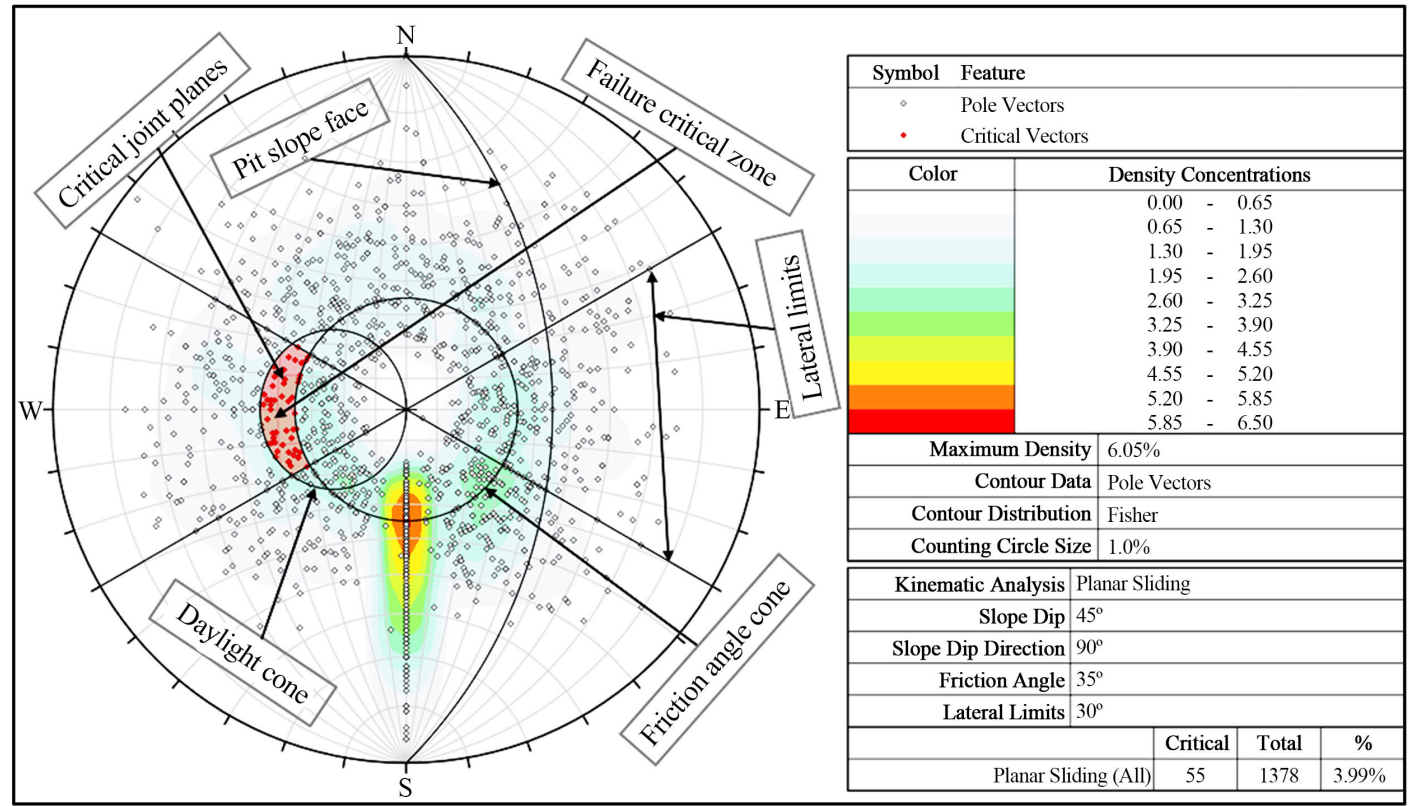

Figure 6. Planar slope stability condition in east facing pit slope at an angle of $45^{\circ}$. 


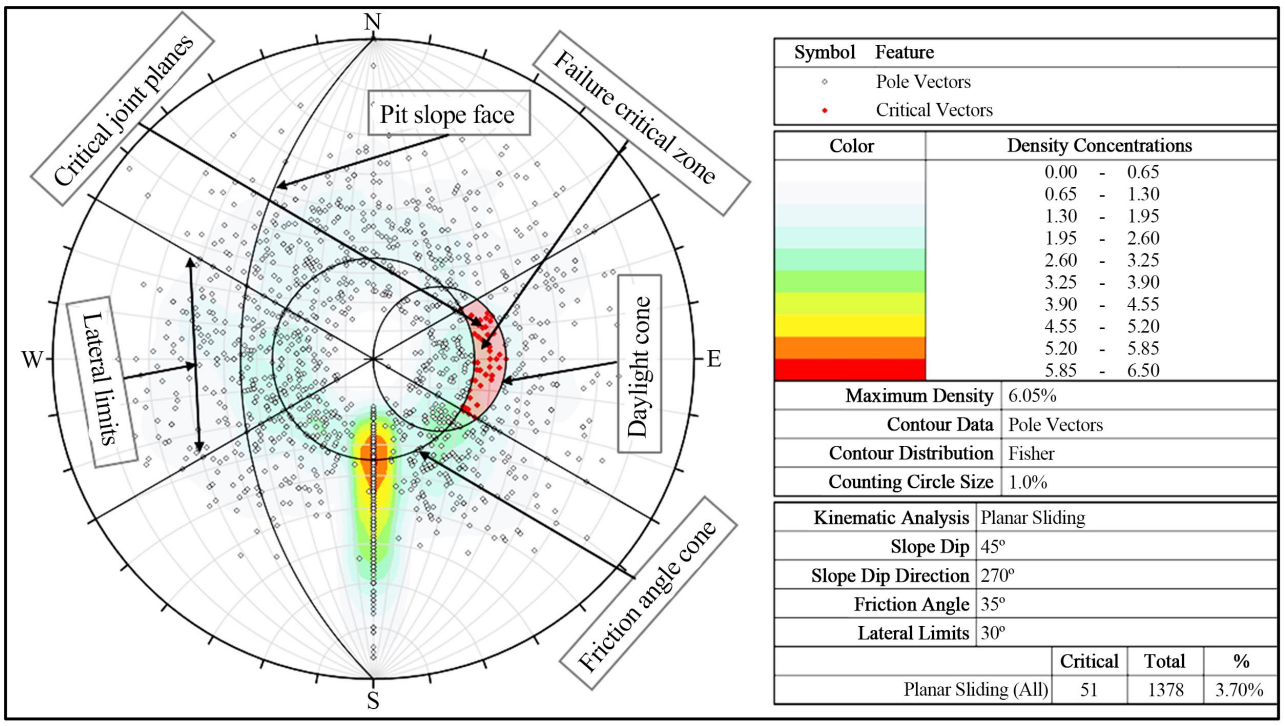

Figure 7. Planar slope stability condition in west facing pit slope at an angle of $45^{\circ}$.

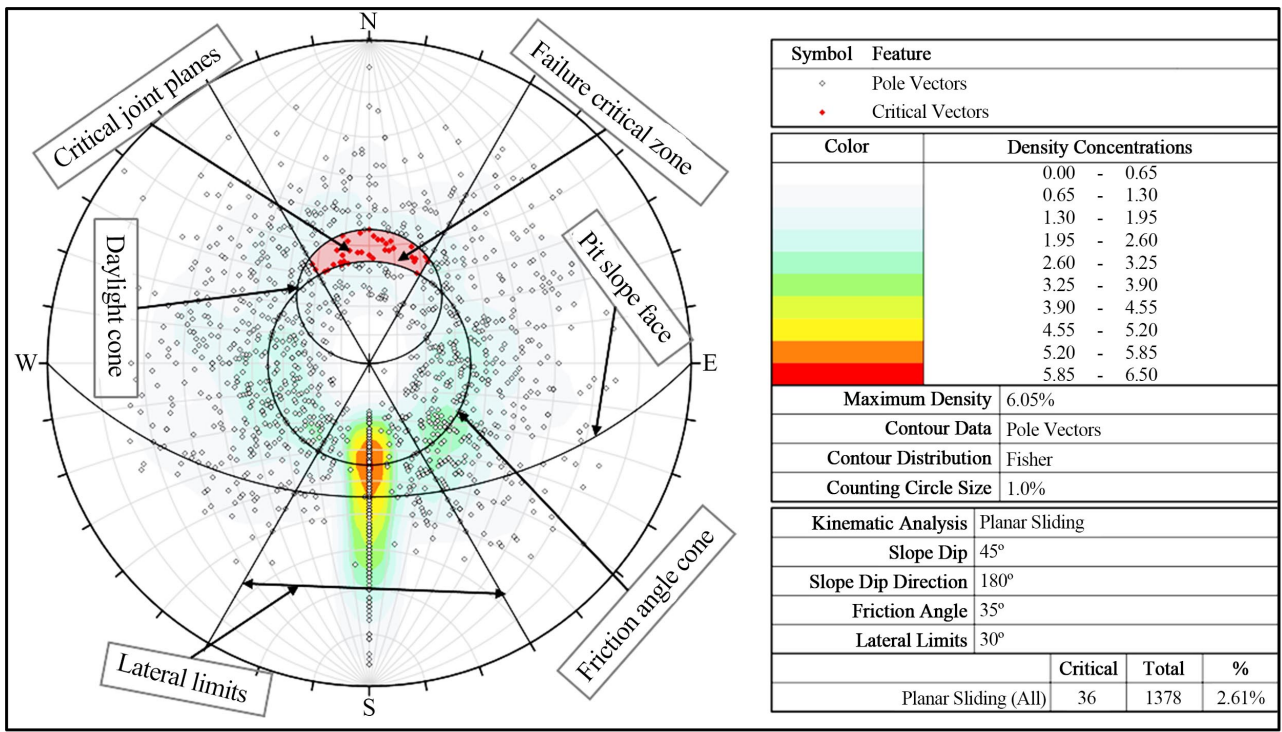

Figure 8. Planar slope stability condition in south facing pit slope at an angle of $45^{\circ}$.

After running a series of analyses, a slope angle of $41^{\circ}$ is proposed by the authors for consideration. The $3^{\circ}$ reduction of the overall slope angle (OSA) demonstrates that the sectional risk of potential planar failure could be reduced by $35 \%, 59 \%, 46 \%$ and $35 \%$ in the North, East, South and West facing slopes respectively (Figures 9-12). This represents an overall 44\% reduction of planar failure risk for the entire mine. The average sectional probability at this OSA is 9\% (Figure 13(b)) which falls in the optimal value range of the acceptable probability risk of slope instability [8] [17].

\subsubsection{Wedge Failure}

Wedge failure can only occur on two intersecting planes of the joints. Generally, the trend of the intersection line that satisfies wedge failure must be orientated 
within $90^{\circ}$ of the dip and the plunge of the intersection line must "daylight" in the slope face implying that the dip of the slope face has to be greater than the plunge of the intersection line [4] [5] [6]. In this kinematic analysis, all sections of the planned open pit registered no critical intersections in the potential failure zones both in the primary and secondary zone (Figures 14-17). Within the primary critical zone, any intersection plotted could directly satisfy the frictional and kinematic conditions for wedge failure. On the contrary, the intersection in the secondary critical zone would be such that the sliding would occur on a joint plane with a dip greater than the friction angle and the other joint acting as a release plane for wedge failure. Since no intersections plotted in the critical zones of potential failure, wedge failure could be an unlikely phenomenon unless artificial propagation of joint planes under active mining operations.

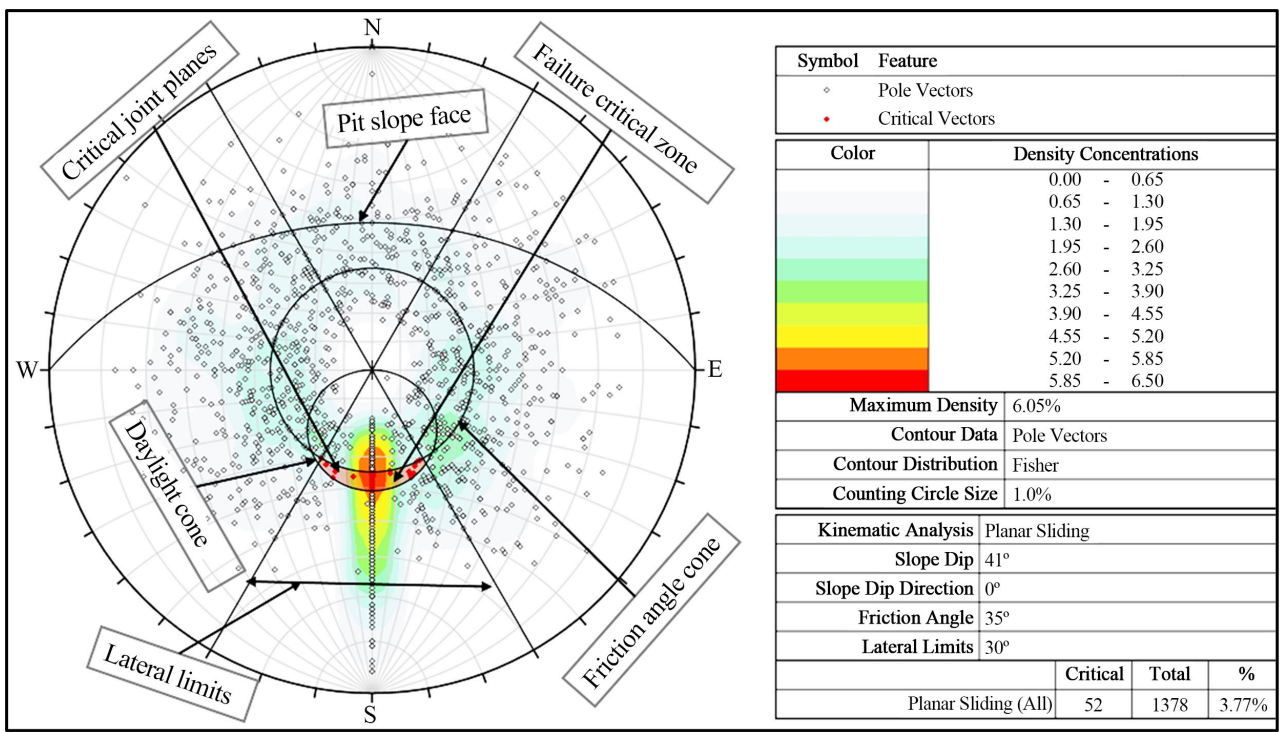

Figure 9. Planar slope stability condition in north facing pit slope at an angle of $41^{\circ}$.

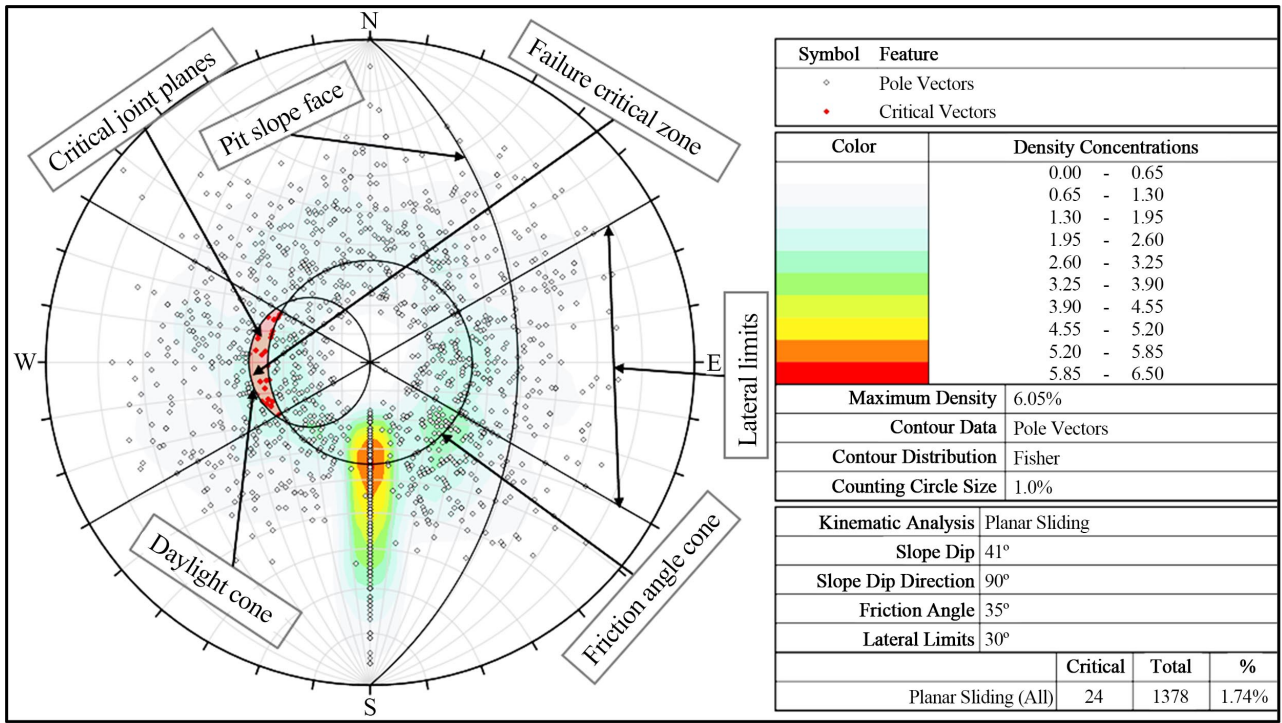

Figure 10. Planar slope stability condition in east facing pit slope at an angle of $41^{\circ}$. 


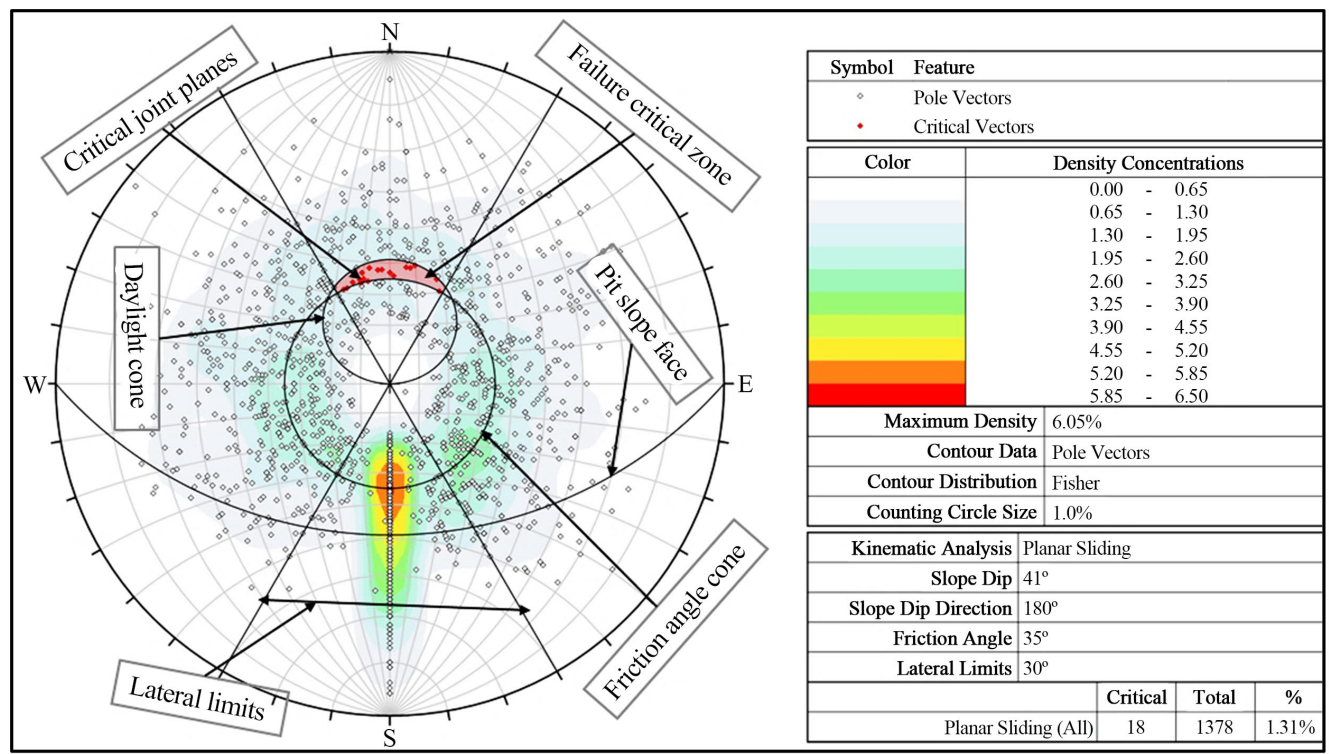

Figure 11. Planar slope stability condition in south facing pit slope at an angle of $41^{\circ}$.

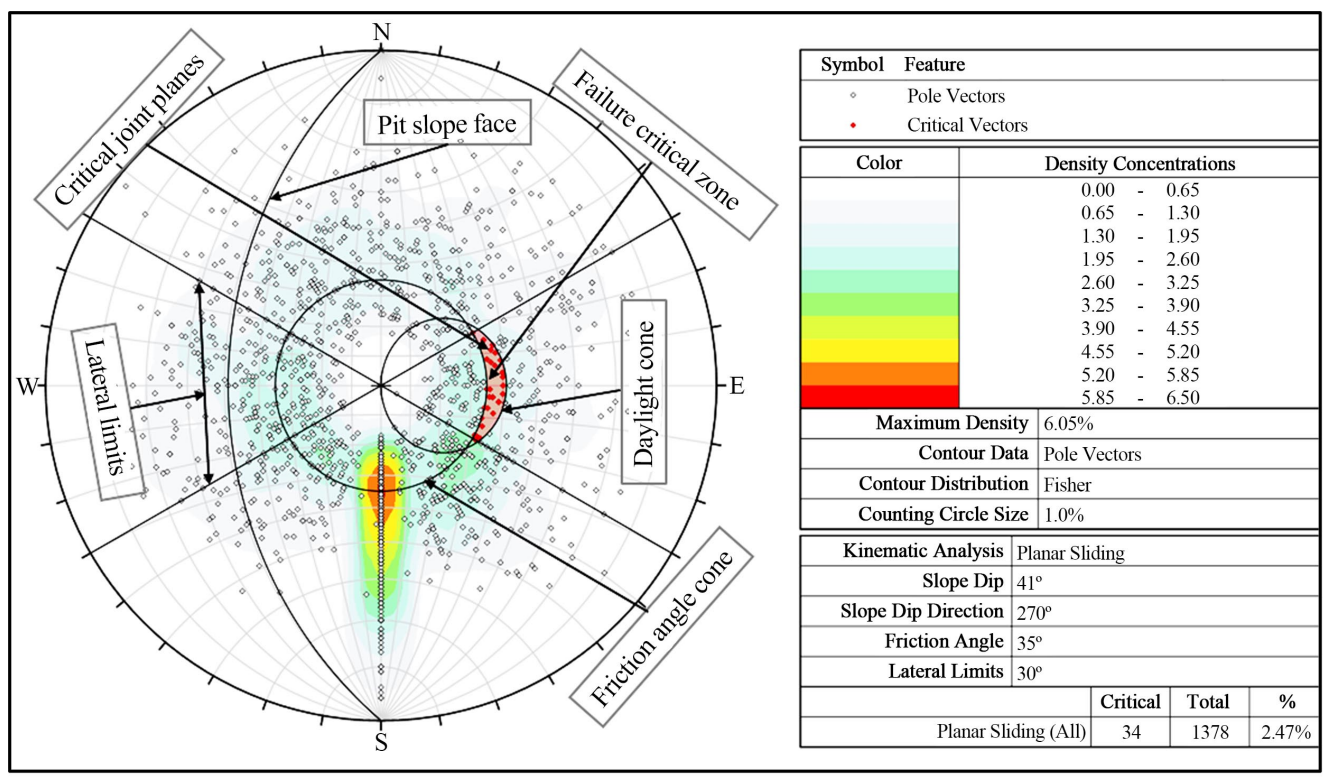

Figure 12. Planar slope stability condition in west facing pit slope at an angle of $41^{\circ}$.

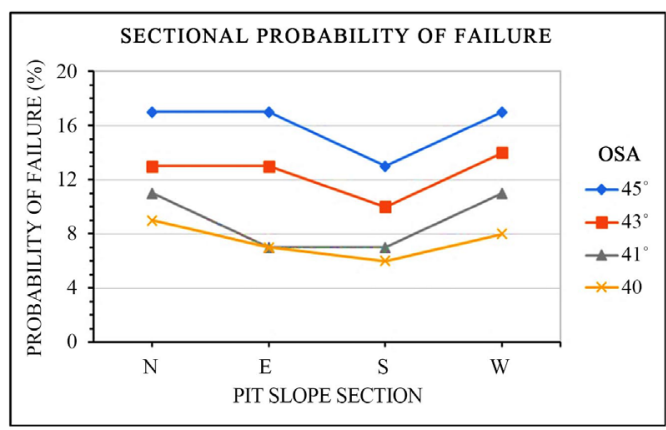

(a) Mine sectional failure probability

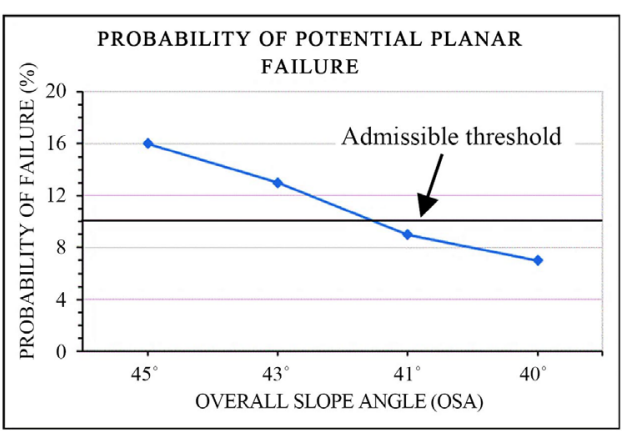

(b) Mine overall sectional failure probability

Figure 13. Probability of potential planar failure. 


\subsection{Numerical Analysis}

\subsubsection{Pit Height and Slope Stability}

In slope stability, FOS is used to determine the stability conditions. FOS is a ratio between supply (shear strength) and demand (shear stress). The minimum requirement for stability is that FOS should be at unity. However, in mines, the standard used criterion for safety assurance is for FOS to be $\geq 1.2$ [8] [33]. Figure 18 presents the stability conditions evaluated in case 1 where the height is at 250 $\mathrm{m}$. As aforementioned, the OSA was varied from $45^{\circ}$ to $40^{\circ}$. At $45^{\circ}$ the FOS is 1.22 which is reasonably satisfactory for mine stability. When the OSA is successively reduced to $43^{\circ}, 41^{\circ}$ and $40^{\circ}$, in turn, FOS increases from 1.29, 1.32 and 1.34 respectively. Thus, OSA in inversely proportional to FOS.

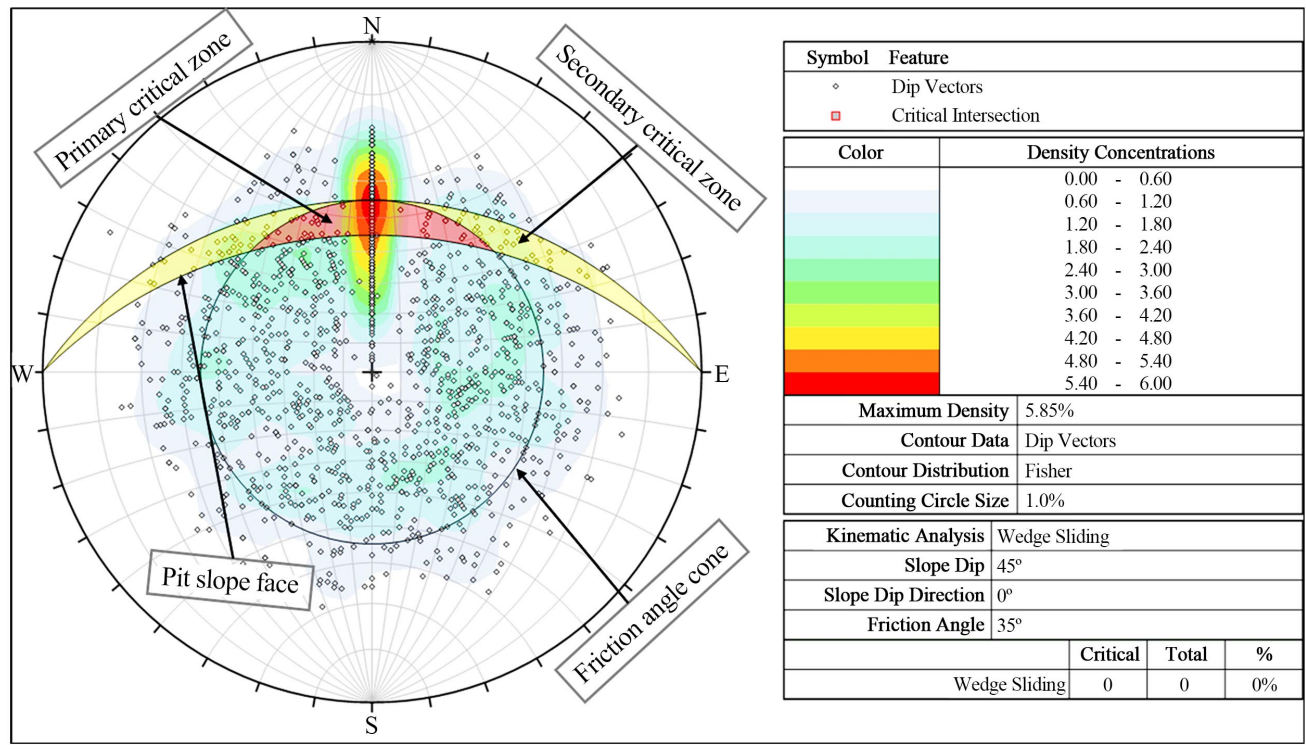

Figure 14. Wedge slope stability condition in north facing pit slope at an angle of $45^{\circ}$.

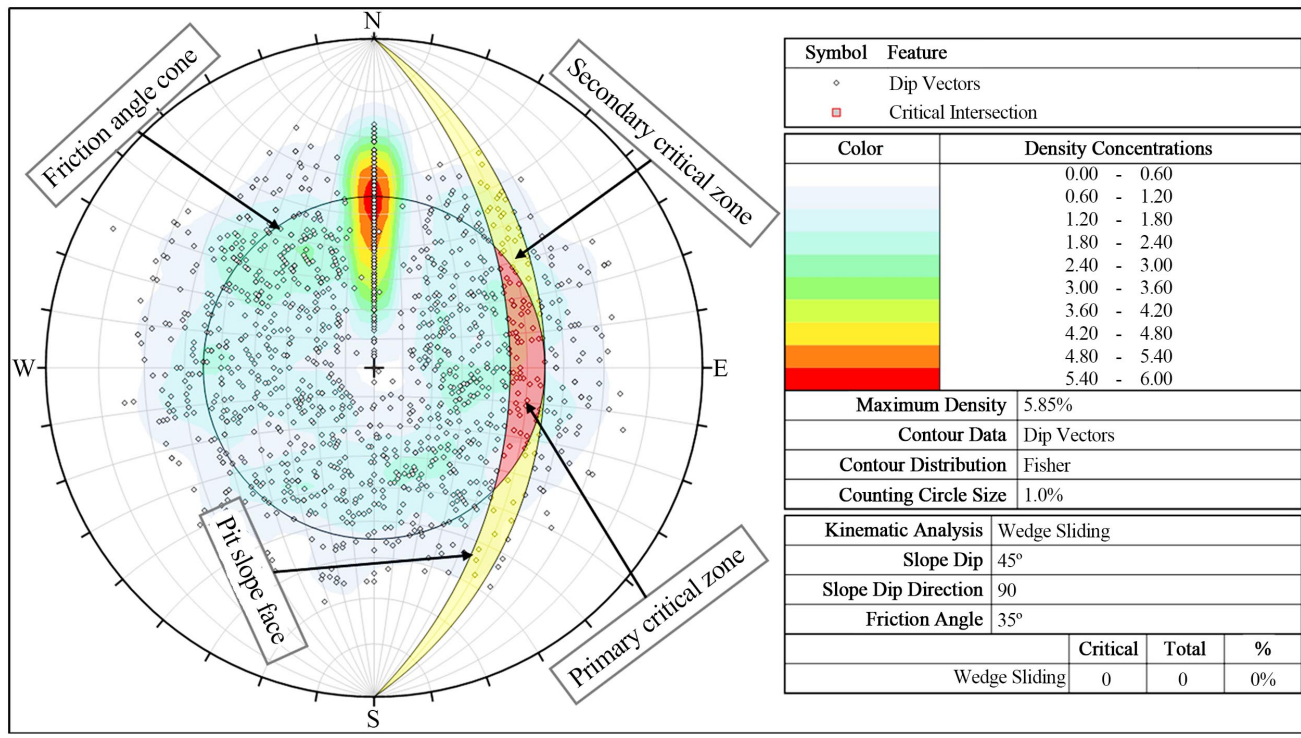

Figure 15 . Wedge slope stability condition in east facing pit slope at an angle of $45^{\circ}$. 


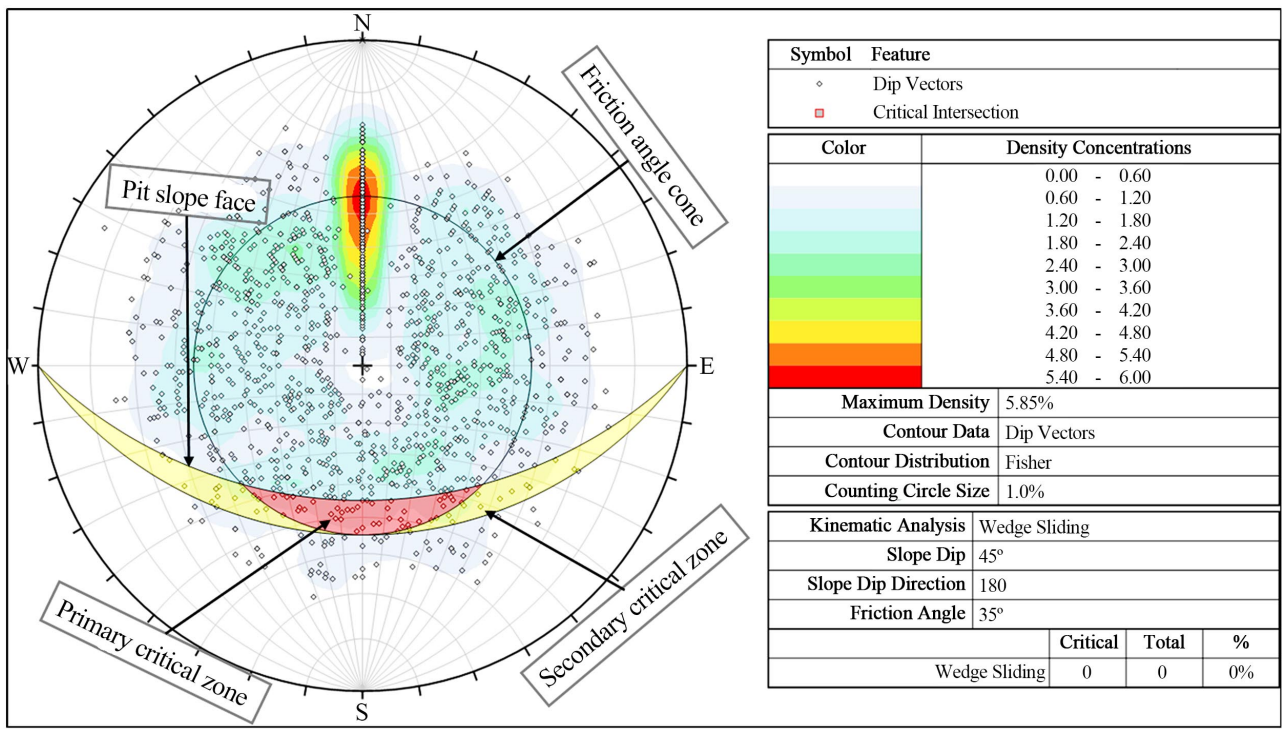

Figure 16. Wedge slope stability condition in south facing pit slope at an angle of $45^{\circ}$.

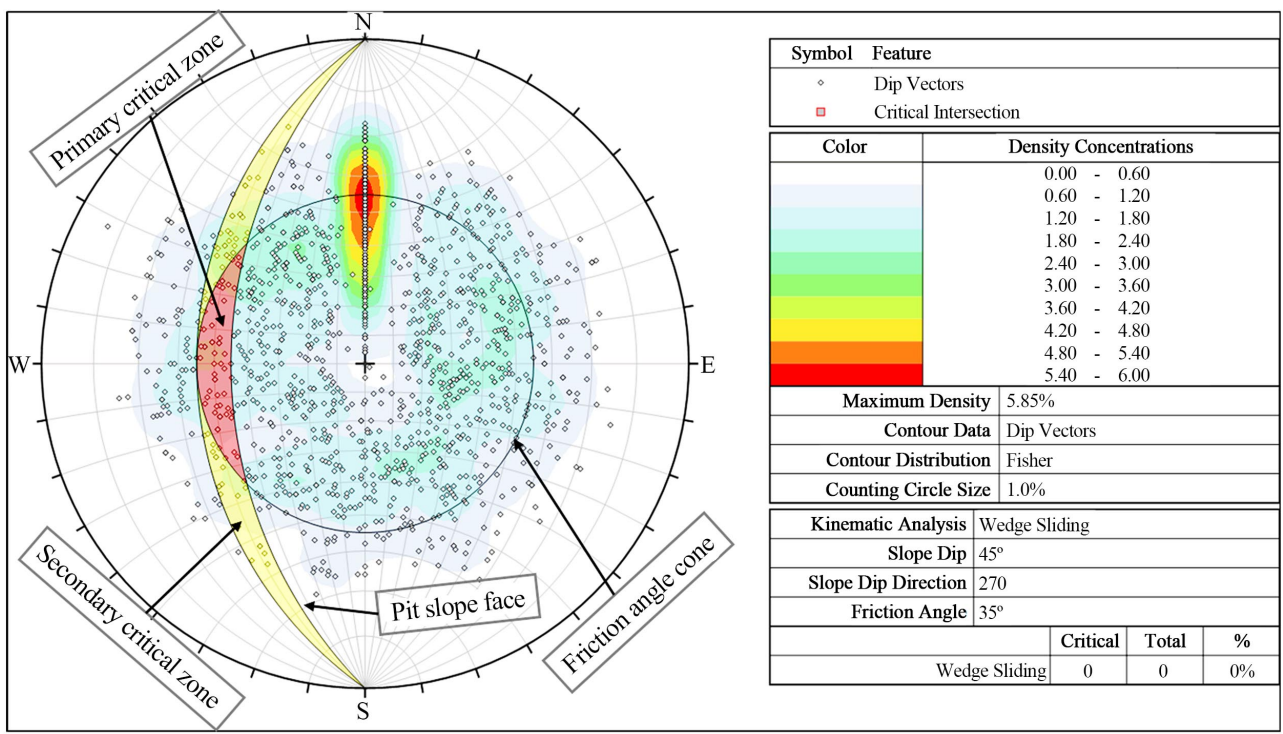

Figure 17. Wedge slope stability condition in west facing pit slope at an angle of $45^{\circ}$.

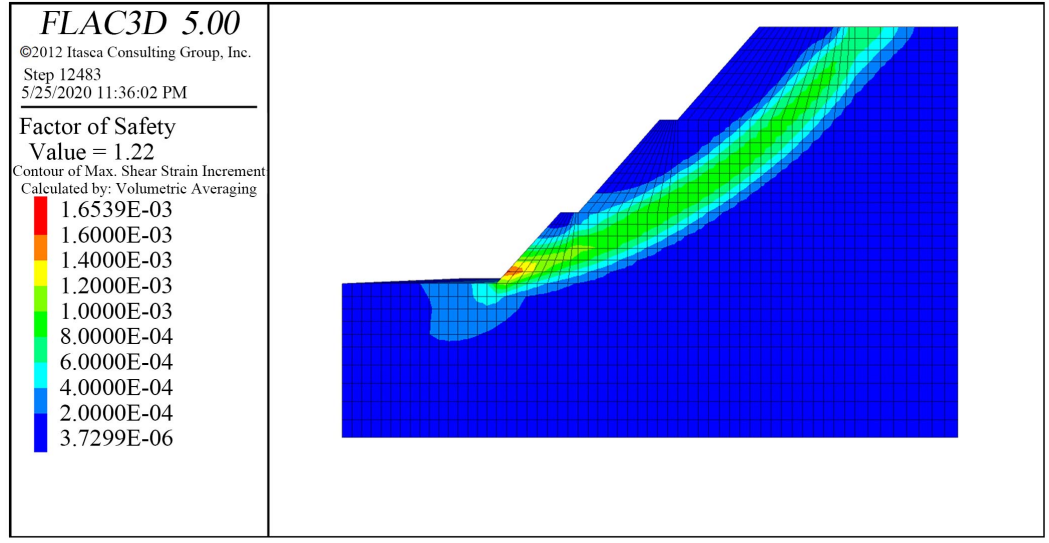

Stability condition at $45^{\circ}$ OSA 


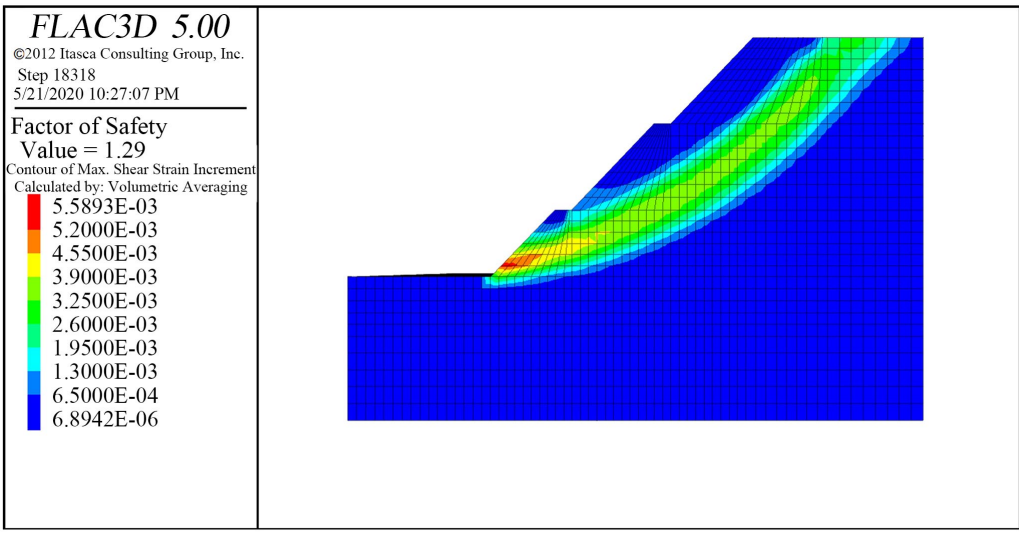

Stability condition at $43^{\circ}$ OSA

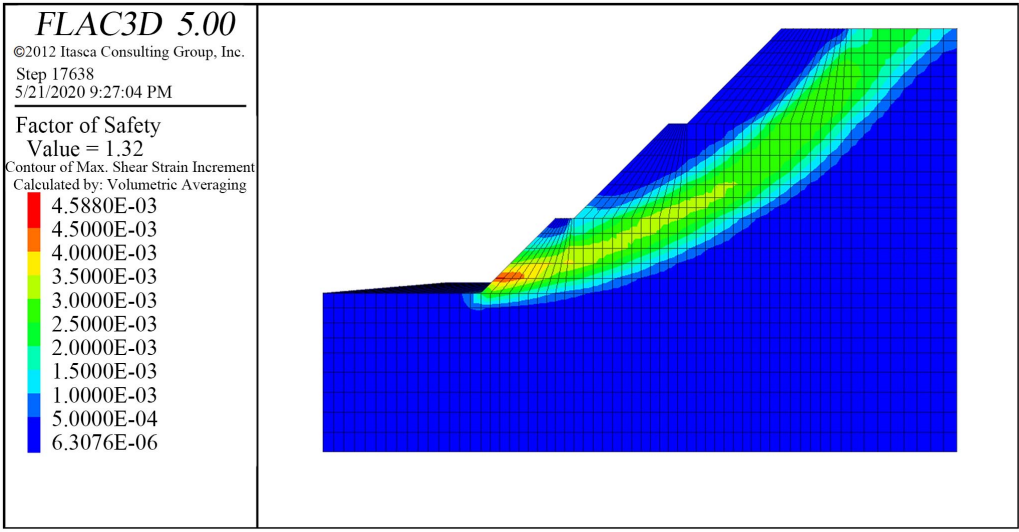

Stability condition at $41^{\circ} \mathrm{OSA}$

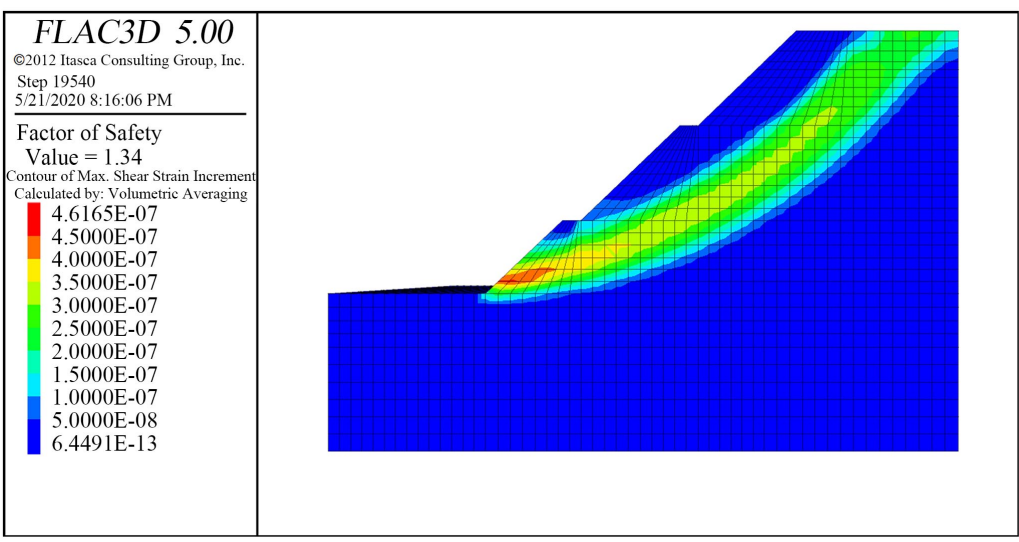

Stability condition at $40^{\circ} \mathrm{OSA}$

Figure 18. Pit wall stability condition at $250 \mathrm{~m}$ height.

In order to assess the influence of height on slope stability as the pit extends to deeper horizons, the height was set at ultimate pit limit (UPL) of $300 \mathrm{~m}$ deep in case 2. The OSA variable remained constant as in case 1. The results are shown in Figure 19. The results show that the trend of relationship between FOS and OSA is the same. However, the values of FOS are low relative to case 1 indicating that increase in height compromises stability conditions on pit slopes. The FOS values in case 2 are below the recommended minimum standard values for pit 
wall stability at $45^{\circ}$ and $43^{\circ}$ (Figure 19). On the other hand, it can be noted that the FOS values are still reliable at OSA of $41^{\circ}$ and $40^{\circ}$. The FOS at $40^{\circ}$ which is 1.26 is more reliable than the FOS at $41^{\circ}$ (1.22). Nevertheless, in mining, efforts are made to balance between safety and mining economic profits. That entails making slope angle steeper and high to avoid excavating much waste without effecting instability. In the event that the mine extends to $300 \mathrm{~m}$, then it would be recommendable to optimise the OSA to $41^{\circ}$. The proposed optimisation option at the initiation of the mining operation could assist in evading costs due to push backs or onset of instabilities. For instance, a study by Bye and Bell (2001) [34], demonstrated that the optimization of slope design at Sandsloot Platinum mine extended the life of mine allowing for more two benches after the $300 \mathrm{~m}$ planned depth and enabled the company to generate over 1.2 billion Rand in additional revenue. Meilnikov et al. (2003) [35] also acknowledge that there are substantial economic benefits of steepening the front-to-back to optimal slope angle which ups the ultimate value to tens of millions of US\$ in medium-sized open pits to hundred million of US\$ in large pits. However, examples of over-optimising the angle at the expense of safety are hinted which experienced loss in stability in the zones of pit walls and greatly worsened the mining operations resulting in losses [35].

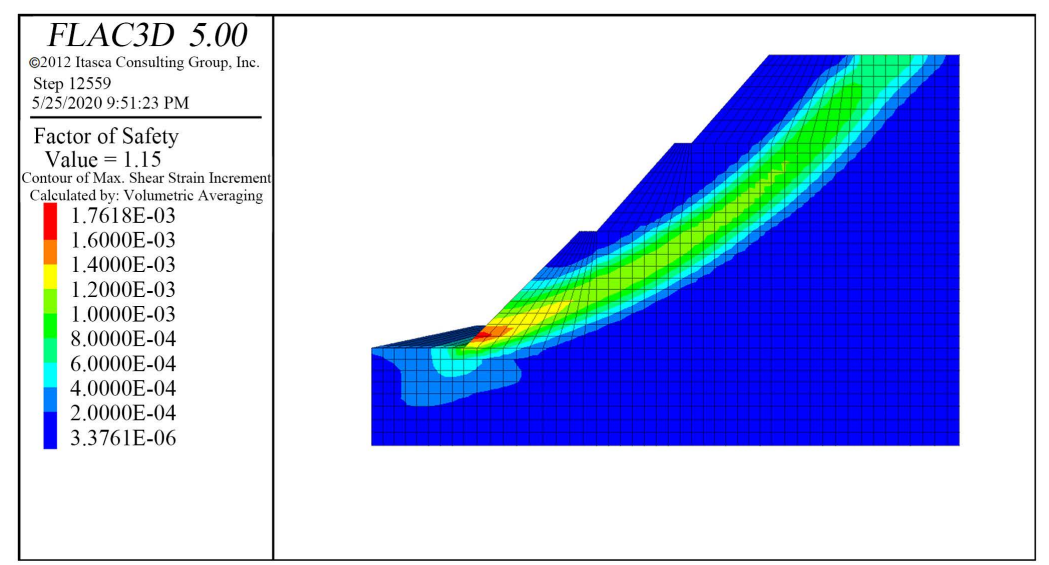

Stability condition at $45^{\circ}$ OSA

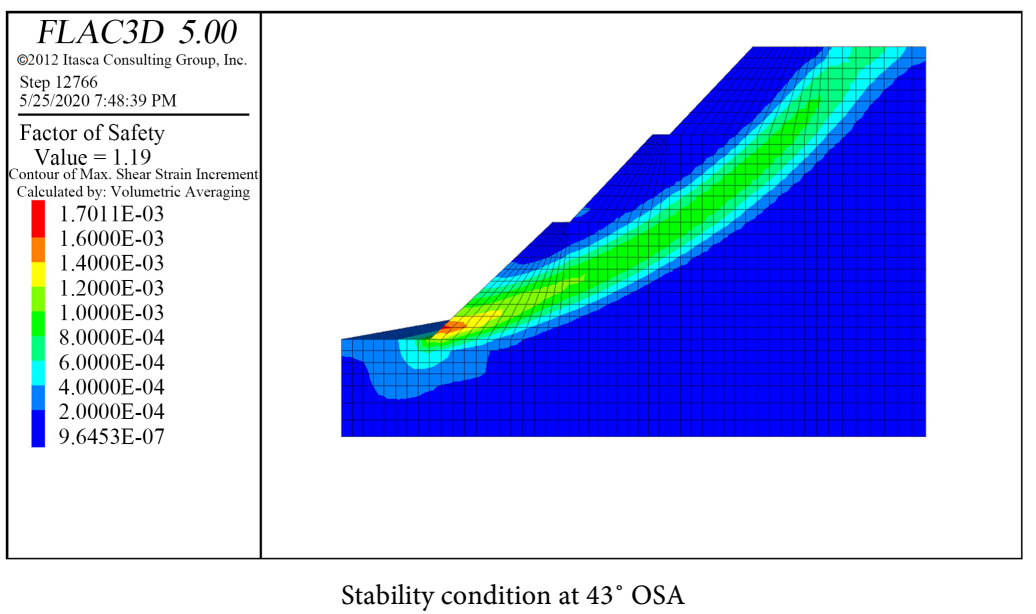




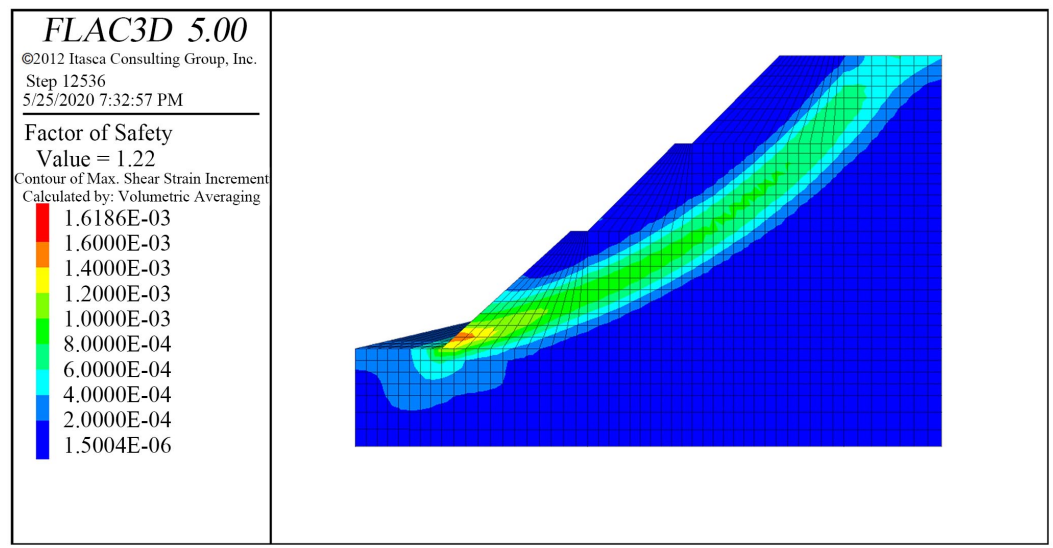

Stability condition at $41^{\circ} \mathrm{OSA}$

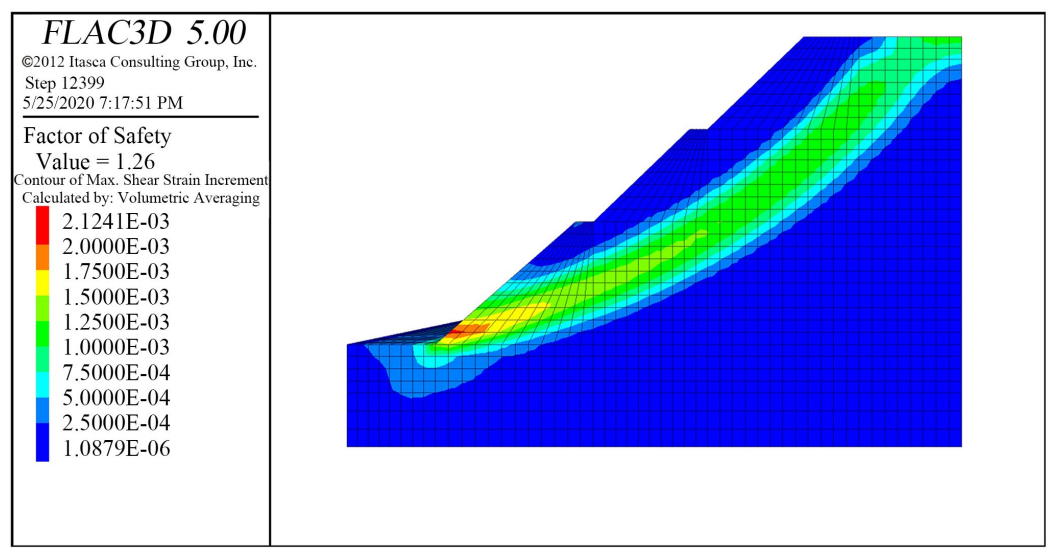

Stability condition at $40^{\circ}$ OSA

Figure 19. Pit wall stability condition at $300 \mathrm{~m}$ height.

To establish the extent of rock material movement on the mine pit wall, horizontal displacement was assessed. The results of the $\mathrm{x}$-displacement are presented in Figure 20. It can be observed that horizontal displacement increases with increase in slope angle. In both cases, the $\mathrm{x}$-displacement is high at $45^{\circ}$ and the lowest at $40^{\circ}$. However, at $250 \mathrm{~m}$ pit height, maximum horizontal displacement is recorded in the second stage of excavation with the values $0.17 \mathrm{~m}, 0.16$ $\mathrm{m}, 0.14 \mathrm{~m}$ and $0.13 \mathrm{~m}$ at $45^{\circ}, 43^{\circ}, 41^{\circ}$ and $40^{\circ}$ respectively (see Figure 20(a)). On the contrary, horizontal displacement is highest in the third excavation at the depth of $300 \mathrm{~m}$ (Figure 20(b)). However, compared to the maximum displacements at $250 \mathrm{~m}$, the horizontal displacement values at $300 \mathrm{~m}$ depth are lower. The recorded maximum $\mathrm{x}$-displacement values at $300 \mathrm{~m}$ range from $0.06 \mathrm{~m}$, $0.056 \mathrm{~m}, 0.053 \mathrm{~m}$ and $0.051 \mathrm{~m}$ at $45^{\circ}, 43^{\circ}, 41^{\circ}$ and $40^{\circ}$ respectively. The established results are corroborated by the findings in a study by Singh et al. (2003) [36] where decreasing displacement with increasing depth of excavation was noticed and supported by physical models.

This phenomenon can be attributed to stress distribution on the slope face. The high maximum principal stress concentration observed at the toe region due to gravity loading and angle of pit slope is reduced towards the crest as a result 


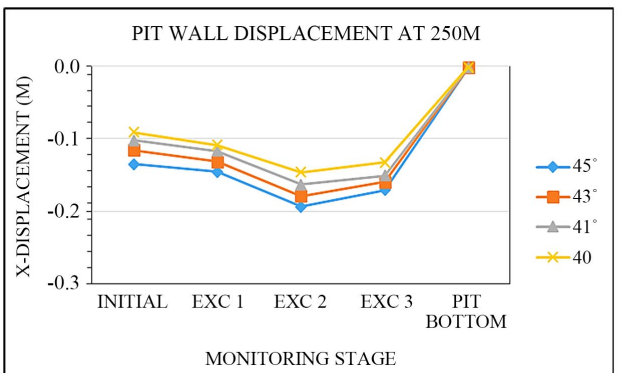

(a)

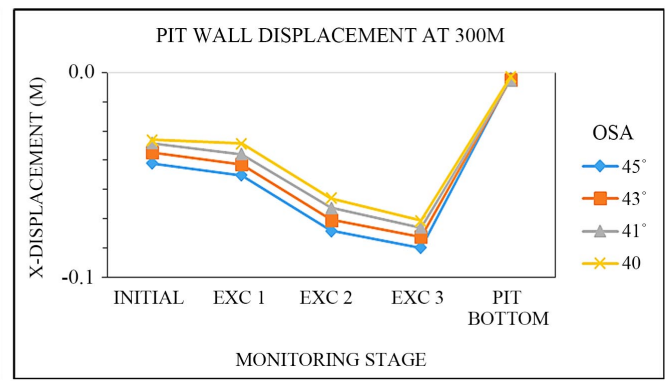

(b)

Figure 20. Horizontal displacement of rock mass on the pit wall.

of thrusting from the bottom where the minimum principal stress is at low concentration. Similarly, maximum shear stress concentration reduces towards the crest of the slope. Tensile stress, which is not significant in as far as failure is concerned, is developed on the upper portion of the slope face. These stress interactions transform the confined state of stress into unconfined state due to the excavation of the pit. Furthermore, the length of the slope face provides for stress release in the redistribution of stresses. This could account for the small displacement values in the pit wall at increased excavation depth.

\subsubsection{Significance of GSI in Slope Stability Analysis}

Since rock condition has a direct impact on rock behavior, the values of GSI describing the rock mass state were applied in numerical modelling to establish the strength conditions of the rock slope. The results of the analysis are graphed in Figure 21. The GSI values appear to have a direct proportionality to material stability on the pit slope. At a lower GSI value of 55 , the safety factor is 3.12 , $3.08,3.0$ and 2.9 at $40^{\circ}, 41^{\circ}, 43^{\circ}$ and $45^{\circ}$ respectively. When the GSI value is increased to the upper limit of the rock class, the safety factor increases to 5.75, 5.67, 5.56 and 5.47 at $40^{\circ}, 41^{\circ}, 43^{\circ}$ and $45^{\circ}$ in the order of OSA. The values of rock slope stability for the currently established GSI value are shown in the red outline (Figure 21). The trend corroborates a non-failure condition with all values above unity as observed in the FOS using unadjusted parameters (see Figure 18 and Figure 19). However, the stability condition wane with increase in OSA. Sonmez and Ulusay (1999) [37] in five well-documented slope instability examples that they studied, they included the GSI values in the back analysis of the failed slopes. The outcome indicated that the use of GSI value confirmed the limit equilibrium analysis outcome for the failed slopes in all the cases. Thus, it can be concluded that the use of GSI in stability analyses gives an insight of the slope strength conditions of rock mass to failure.

\section{Conclusions}

In this paper, potential slope failure modes and stability conditions of the pit slope were investigated using kinematic and numerical approaches.

The kinematic analysis of the planned mine at Songwe carbonatite complex revealed a potential planar slope instability at a high possible OSA of $45^{\circ}$. The 


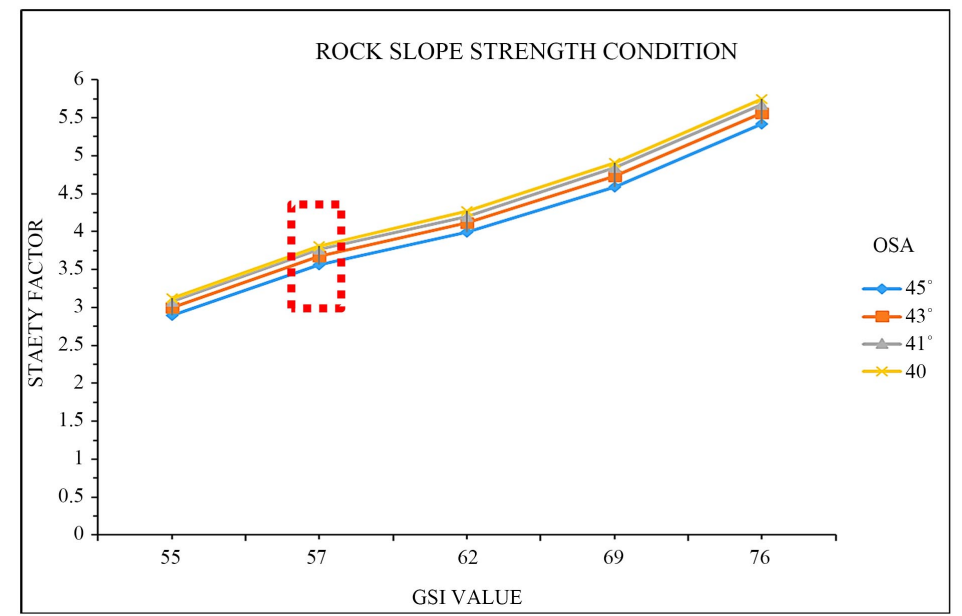

Figure 21. Application of GSI in stability analysis.

sectional probability of planar failure was evaluated to be $16 \%$ which is a considerably high value for acceptability. In order to minimise the risk of potential planar failure, slope angle optimisation to $41^{\circ}$ was proposed as a counter-measure. At the optimised angle, the risk of potential planar failure would be reduced by $44 \%$. On the other hand, wedge failure has been found to be an improbable phenomenon since critical intersection that necessitates the failure mode could not be encountered in the zone of potential failure this far.

Complementarily, Numerical analysis demonstrated that an OSA of $41^{\circ}$, would offer a favourable balance between safety and mining economics as mining operations progress to the ultimate pit height of $300 \mathrm{~m}$. Slope heightening and steepening of excavation bench slopes leading to high OSA may affect the security of pit wall slopes thereby inducing instability in which case the solution would be a costly push back. Thus, from the project initiation, angle of $41^{\circ}$ is recommended for adoption. The results of numerical analysis are quite in agreement with the kinematic analysis results for the OSA.

\section{Study Limitations and Recommendations}

The limitation of the current kinematic analysis is that the assessment of failure modes was largely based on the drill core structural logging data. So, the continuity of the discontinuities across the sections could not be ascertained since there are no excavated faces yet. Therefore, follow up studies are recommended when pit walls get exposed using data from scan line surface mapping to acquire the finer details of the major discontinuities and update the current findings. Furthermore, numerical analysis was undertaken using continuum approach in which the rock mass was treated as isotropic rock mass without incorporating joints. Hence it may not be a realistic representation of the field conditions. In future, authors propose a comprehensive study based on discontinuum approach utilising discrete element method (DEM) to incorporate discontinuities in the numerical model. 


\section{Acknowledgements}

The authors express sincere gratitude to Mkango Resources Company for providing the geotechnical borehole log data for the study to materialise. This research did not receive any specific grant from funding agencies in public, commercial, or not-for-profit sectors.

\section{Conflicts of Interest}

The authors declare no conflicts of interest regarding the publication of this paper.

\section{References}

[1] Eberhardt, E. (2003) Rock Slope Stability Analysis-Utilization of Advanced Numerical Techniques. Earth and Ocean Sciences at UBC, Vancouver.

[2] Llano-Serna, M.A., Williams, D.J. and Ruest, M.R. (2016) Analysis of Kennecott Utah Copper's Biggham Canyon Mine Pit Wall Slides. Tailings and Mine Waste 2016, Keystone, 2-5 October 2016, 787-794.

[3] Smith, J.V. and Arnhardt, C. (2016) A New Assessment Method for Structural-Control Failure Mechanisms in Rock Slopes-Case Examples. AIMS Geosciences, 2, 214-230. https://doi.org/10.3934/geosci.2016.3.214

[4] Goodman, R.E. (1989) Introduction to Rock Mechanics. 2nd Edition, John Wiley and Sons, Hoboken.

[5] Hoek, E. (2005) Rock Slope Engineering. 4th Edition, The Institute of Mining and Metallurgy, New York.

[6] Wyllie, D.C. and Mah, W.C. (2004) Rock Slope Engineering. 4th Edition, Taylor \& Francis Group, New York.

[7] Sjoberg, J. (1996) Large Scale Slope Stability in Open Pit Mining. Lulea University of Technology: Division of Rock Mechanics, Lulea.

[8] Read, J. and Stacey, P. (2010) Guidelines for Open Pit Slope Design. SCIRO Publishing, Clayton. https://doi.org/10.1071/9780643101104

[9] Mogorosi, O., Gabanakgosi, K., Barei, O.M. and Thokweng, T. (2017) Slope Stability Challenges and Solutions for Mining Kimberlite Resources Hosted in Structurally Complex Country Rock: Dip Slope Mining at Jwaneng Mine, Botswana. International Kimberlite Conference, Gaborone, Vol. 11, 1-3.

[10] Tunono, A.B. and Dimbungu, L. (2010) Jwaneng Open Pit Mine Cut 8 South East Wall Slope Design. The Southern African Institute of Mining and Metallurgy, Johannesburg, South Africa.

[11] Stead, D. (2015) The Influence of Shales on Slope Instability. Rock Mechanics and Rock Engineering, 49, 635-651. https://doi.org/10.1007/s00603-015-0865-0

[12] Tuckey, Z., Stead, D. and Eberhardt, E. (2013) Combining Field Methods and Numerical Modelling to Address Challenges in Characterising Discontinuity Persistence and Intact Rock Bridges in Large Open Pit Slopes. Australian Centre for Geomechanics, Perth. https://doi.org/10.36487/ACG_rep/1308_07_Tuckey

[13] Stacey, T.R. (2007) Slope Stability in High Stress and Hard Rock Conditions. Australian Centre for Geomechanics, Perth.

https://doi.org/10.36487/ACG_repo/708_Stacey

[14] Rocscience (2019) rocscience.com. 
https://www.rocscience.com/help/dips/dips/Kinematic_Analysis_Overview.htm

[15] Zhou, X., Chen, J., Chen, Y., Song, S., Shi, M. and Zhan, J. (2016) Bayesian-Based Probabilistic Kinematic Analysis of Discontinuity-Controlled Rock Slope Instabilities. Bulletin of Engineering Geology and the Environment, 76, 1249-1262. https://doi.org/10.1007/s10064-016-0972-5

[16] Singh, T. and Rao, K.S. (2016) Kinematic Stability Analysis of Multi-Faced Rock Slopes in the Himalayas. Proceedings of the Conference on Recent Advances in Rock Engineering, Amsterdam, The Netherlands, 281-284.

[17] Obregon, C. and Mitri, H. (2019) Probabilistic Approach for Open Pit Bench Slope Stability Analysis-A Mine Case Study. International Journal of Mining Science and Technology, 29, 629-640. https://doi.org/10.1016/j.ijmst.2019.06.017

[18] Kincal, C. (2014) Application of Two New Stereographic Projection Techniques to Slope Stability Problems. International Journal of Rock Mechanics \& Mining Sciences, 66, 136-150. https://doi.org/10.1016/j.ijrmms.2014.01.006

[19] Fleurisson, J.A. (2012) Slope Design and Implementation in Open Pit Mines. Geological and Geomechanical Approach. Procedia Engineering, 46, 27-38. https://doi.org/10.1016/j.proeng.2012.09.442

[20] Al Mandalawi, M., You, G., Dowling, K. and Dahlhaus, P. (2016) Kinematic Assessment of Slopes at Handlebar Hill Open Cut Mine. International Journal of GEOMATE, 10, 1575-1583. https://doi.org/10.21660/2016.19.09509

[21] Croll, R., Swinden, S., Hall, M., Brown, C., Beer, G., Scheerpers, J. and Trusler, G.E. (2014) NI 43-101 Pre-Feasibility Report. MSA Group (Pty) Ltd., Johannesburg.

[22] Garson, M.S. and Smith, C.W. (1965) Carbonatite and Agglomeratic Vents in the Western Shire Valley. Geological Survey Department, Malawi.

[23] British Geological Survey (2009) Malawi Potential of Malawi. Malawi Government, Malawi.

[24] Broom-Fendley, S., Brady, A.E., Horstwood, M.S., Woolley, A.R., Mtegha, J., Wall, F. and Gunn, G. (2017) Geology, Geochemistry and Geochronology of the Songwe Hill Carbonatite, Malawi. Journal of African Earth Sciences, 134, 10-23. https://doi.org/10.1016/j.jafrearsci.2017.05.020

[25] Witley, J.C., Swinden, S., Trusler, G. and Dempers, N. (2019) Songwe Hill Rare Earth Elements (REE) Project, Phalombe District, Malawi. MSA Group, Randburg.

[26] Ulusay, R. (2015) The ISRM Suggested Methods for Rock Characterization, Testing and Monitoring: 2007-2014. Springer International Publishing, Berlin. https://doi.org/10.1007/978-3-319-07713-0

[27] Bieniawski, Z.T. (1989) Engineering Rock Mass Classification: A Complete Manual for Engineers and Geologists in Mining, Civil and Petroleum Engineering. John Wiley and Sons, Toronto.

[28] Itasca (2012) Fast Lagrangian Analysis of Continua in 3Dimensions User's Guide. Fifth Edition, Itasca Consulting Group Inc., Minneapolis.

[29] Rocscience.com (1996) rocscience.com. https://www.rocscience.com/downloads/roclab/RocLabManual.pdf

[30] Singh, B. and Goel, K.R. (2011) Engineering Rock Mass Classification: Tunneling, Foundations, and Landslides. Butterworth-Heinemann, Oxford. https://doi.org/10.1016/B978-0-12-385878-8.00011-2

[31] Hoek, E., Carter, T.G. and Diederichs, M.S. (2013) Quantification of the Geological Strength Index chart. American Rock Mechanics Association, San Francisco.

[32] Kliche, C.A. (1999) Rock Slope Stability. Society for Mining, Metallurgy, and Ex- 
ploration, Inc., Littleton.

[33] Adams, B.M. (2015) Slope Stability Acceptance Criteria for Opencast Mine Design. Golder Associates (NZ) Limited, Christchurch.

[34] Bye, A.R. and Bell, F.G. (2001) Stability Assessment and Slope Design at Sandsloot Open Pit, South Africa. International Journal of Rock Mechanics \& Mining Sciences, 38, 449-466. https://doi.org/10.1016/S1365-1609(01)00014-4

[35] Singh, T.N., Puri, S. and Pandey, A. (2003) Stability of Rock Slopes in Complex Rock Formation. In: Deformation Characteristics of Geomaterials, A.A. Balkema, Lisse, 947-954.

[36] Melnikov, M.N., Kozyrev, A.A., Reshetnyak, S.P., Kasparian, E.V. and Rybin, V.V. (2003) Geomechanical and Technical Substantiation of an Optimal Slope Angle in the Kovdor Open Pit. In: Udd, J.E. and Bekkers, G., Eds., Mining in the Arctic, CIM, Kola, Russia, 321-327.

[37] Sonmez, H. and Ulusay, R. (1999) Modifications to the Geological Strength Index (GSI) and Their Applicability to Stability of Slopes. International Journal of Rock Mechanics and Mining Sciences, 36, 743-760.

https://doi.org/10.1016/S0148-9062(99)00043-1 